The Abstract of the Thests

Name of Author :

Title of thesis:

Department :

Degree sought:
Jonathan Atta KUSI

The Right of Self-Determination in International Law.

Institute of Comparative and Foreignj Law.

LL.M.

Summary of thesis: The concept dif the self-determination of peoples merely proclaims a political desideratum and despite the frequent use of the word 'right' in apposition to "the self-determination of peoples", international law does not provide for a legal right of self-determination vested in entities which are designated as 'peoples'. Essentially, the two factors of structural ineffectiveness and substantive hyper-ambiguity are responsible for this legal position. In other words, there is not a legal right of self-determination of peoples, firstly because the provisions of certain multipartite treaties which allegedly provide for the oright, do not, upon proper legal construction, evince the alleged right and secondly, because both in those treaties and in customary international law, neither the substance of the right nor the holders of that right are sufficiently identified or identifiable to meet minimum juridical standards of definiteness. 
Short Title: WEE RIGET OF SELF-DETERMINATION IN INTERNATIONAI ILAW

Name: Jonathan Atta KUSI 


\section{THE RIGHT OF SELF-DETERMINATION IN}

\section{INTERNATIONAL IAAW}

BY

JONATHAN ATTA KUSI, LI.B. (Legon)

A thesis submitted to the Faculty of Graduate Studies and Research in partial fulfilment of the requirements for the degree of Master of Laws.

Institute of Comparative \& Foreign Law McGill University

Montreal

Quebec Province

Canada.

March 31, 1970.

C) Jonathan Atta Kusi 1970 
For introducing me to the challenging subject of international protection of human rights, and for his guidance and encouragement throughout the whole course of my study at McGill University, much appreciation is expressed to Professor J.P. Humphrey. 
TABLE OF CONTENTS

CHAPTER I

INTRODUCTION

PREFATORY REMARKS

SCHEME OF PAPER

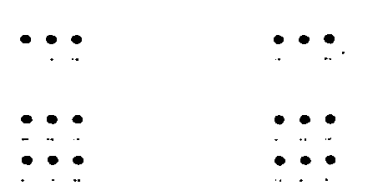

$1-13$

1

5

CHAPTER II

THE BACKGROUND TO THE CONCEPT OF

SELF-DETERMINATION

$\bullet \cdot$

14-27

THE ORIGINS AND SUBSTANCE OF

SELF-DETERMINATION

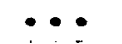

14

THE FIRST WORLD WAR AND AFTER

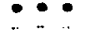

20

ON THE EVE OF WORLD WAR TWO

26

CHAPTER III

THE REVIVAL OF SELF-DETERMINATION

$28-38$

THE SECOND WORLD WAR AND SELF-

DETERMINATION

-..

$\cdots$

28

DUMBARTON OAKS AND SELF-DETERMINATION

33

SAN FRANCISCO AND SELF-DETERMINATION

34

CHAPTER IV

ARTICLE 1(2) OF THE UNITED NATIONS CHARTER

SELF-DETERMINATION : A CHARTER RIGHT OR

A CHARTER PRINCIPLE?

THE GENERAL PURPORT OF ARTICIE 1(2)

THE PROBLEM PHRASE

a) The search for a meaning $\ldots$

b) Formal Independence and self-determination

c) The Pan-Africanist philosophy

d) The economic constituent of selfdetermination ... ...

e) The legal effect of the vagueness inherent in the expression "the right of selfdetermination of peoples"

f) The lack of intention to create a legal right 
THE INCIDENCE OF OBLIGATION $\ldots$... 61

$\begin{array}{llll}\text { CONCLUSION } & \ldots & \ldots & 62\end{array}$

CHAPTER V

ARTICLE 55 OF THE UNITED NATIONS CHARTER 64-75

OVERLAPPING WITH ARTICLE 1(2) ... , 64

THE VERBAL STRUCTURE OF ARTICLE 55

THE IEGAL SIGNIFICANCE OF U.N. RECOGNITION

OF THE RIGHT OF SELF-DETERMINATION

CHAPTER VI

THE INTERNATIONAL COVENANTS ON ECONOMIC, SOCIAI AND CULTURAI RIGHTS AND ON CIVIL AND POLITICAI RIGHTS

THE GENESIS OF ARTICLE 1

76

THE DRAFTING STAGES

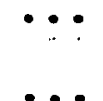

77

THE CONSTRUCTION OF THE ARTICLE ...

a) General Remarks

b) Article 1, paragraph 2

c) Article 1, paragraph 1

d) Article 1, paragraph 3

085

e) Concluding observations

89

93

95

CHAPTER VII

MODERN INTERNATIONAI CUSTOMARY LAW AND THE

RIGHT OF SELF-DETERMINATION

97-111

OPENING REMARKS

THE EMERGENCE OF A NEW CUSTOMARY

RULE OF LAW

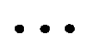

-..

98

EVIDENCE OF INTERNATIONAL CONSENSUS

101

SELF-DETERMINATION AS A MODERN CUSTOMARY

RIGHT IN INTERNATIONAL LAW?

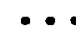

105

CONCLUSION

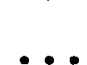

111 
CHAPTER VIII

CONCLUSION

BIBLIOGRAPHY
$112-120$

$i-v i i$

t. 
CHAPTER I

\section{INTRODUCTION}

\section{PREFATORY REMARKS}

The end of the Second World War saw the start of a new wave of nationalist agitations in many colonial territories. In those agitations, much reliance was placed on the concept of the self-determination of peoples. At least, two of the factors militating for the use of the principle of self-determination as the rallying concept may be briefly identified here.

First, as a political principle, the concept is, even merely on its face, highly attractive and, in addition, the moral argument that is inherent in it is almost unanswerable. Few people, if any, might have had the moral conviction and courage, in the post-war years, to deny in principle the reasonableness of the proposition that all peoples should have their destinies in their own hands. Statesmen of the traditional colonial powers, in attempts to present a plausible rationalization for their intention to retain their colonial possessions for as long a time as possible, sometimes disputed the subsidiary question of the 'maturity' of particular colonial peoples to rule them-. selves, but they never attacked in principle the main contention that all peoples should be in a position to determine their political destiny. 
The second factor making for the heavy reliance on the concept of self-determination in the post-World War Two wave of nationalism is that, during the war, the populations of the colonial territories were exposed to, and unconsciously influenced by, the concept which had been reactivated by the facts of the war. Some of the politically ignorant colonial peoples were asked to put in their maximum effort so that Hitler's attempt to rule the whole world would be foiled. They were told that Hitler's objective was wrong and that Germans should rule Germany, the French, France, the British, Britain and so on. Although it was not added that Africans and Asians should respectively rule Africa and Asia, the populations of these two continents drew their own conclusions, and rightly so, that Africans should rule Africa and that Asia should be governed by Asians. The war had indeed performed a sizeable amount of the work of the nationalist leaders in the field of the arousing of the political awareness of the common peoples in the colonies.

Meanwhile, on the international plane, the newly formed United Nations had lent the corporate moral support of the world to the demands for political self-determination, by the favourable references it had made in its Charter to the principle of self-determination. 
In this paper, however, one's concern is not to undertake a discussion or analysis of the politics and the political implications of the principle or concept of self-determination. The objective of the paper is limited to a legal analysis. It will be examined whether or not the concept of the self-determination of peoples has a juridical or normative content within the framework of contemporary international law. Shortly and more specifically put, the goal aimed at in the paper is to establish, on a sound legal basis, that in the international law that currently obtains in this era of the United Nations, there is not a legal right ${ }^{l}$ to self-determination.

It is hoped that this paper will make some contribution, however small, towards the clearing of the legal mysticism which has been built around the principle of self-determination by many sincere guardians and protectors of human rights. The U.N. itself has contributed

1. A legal right may be defined in this context as an interest in the right-holder, which interest other persons are obliged, by virtue of the law, to respect; compare John Austin's concept of a legal right - he states: "A party has a right, when another or others are bound or obliged by the law, to do or forbear towards or in regard of him." (his emphasis), vide John Austin, Lectures on Jurisprudence, Edited by R. Campbell (Iondon: Sheratt \& Hughes, 5th Edition, 1911), p. 398 . 
immensely to the building of this mysticism. As a result of the progressively built-in pressures exerted at the U.N. by the anti-colonial bloc, the U.N. General Assembly was, by 1965 , not merely recognizing the 'right' of self-determination of all peoples but the Assembly was further inviting all states "to provide material and moral assistance to the national liberation movements in the colonial Territories." 2

In the face of a proliferation of U.N. resolutions recognizing the 'right' of self-determination of peoples, one can understand, without necessarily agreeing to, a learned writer's remark that:

"Notwithstanding denials that such a right of self-determination exists, it must be acknowledged that latterly there has been wider general recognition of the right." 3

One observation which is pertinent at this stage may be made on this remark. At least, from the quoted remark alone, it becomes evident that it will be pretentious for one to suggest even indirectly that the denial of the existence of a right of self-determination is appearing in this paper as a novel proposition. On the other hand,

2. Vide U.N. General Assembly Resolution 2105 (XX) of December $20,1965$.

3. J.G. Starke, An Introduction to International Law (London: Butterworths, 6th Edition, 1967), p. 120. 
it has been observed that many of the people who have shown some interest in the subject of self-determination, have contented themselves with merely affirming or denying the existence of the 'right' without giving any reasons at all. Others have given reasons which are either highly insufficient or altogether legally irrelevant.

One has the conviction that when a very important and controversial question like self-determination is being discussed as a legal issue arising in international law, it is not of much help just to affirm or deny the existence of a right. A fully reasoned and legally relevant basis must be produced in support of either an affirmation or a denial.

This paper is thus intended to meet a challenge, the challenge of producing such a fully reasoned and legally relevant basis for the proposition that there is not a legal right of self-determination of peoples known to the international law that is operating in this era of the U.N..

\section{SCHEME OF PAPER}

After looking at Article 38 of the statute of the International Court of Justice, one can safely assume that a general right of self-determination, if there is 
one, will have to be rooted either in customary international law or in a multilateral international instrument of general application. This basic assumption underlies the scheme to be followed in the paper.

In Chapter Two, the historical origins of the concept of self-determination will be explored. Also the role the concept played during the First World War will be covered. The objective, aimed at in the chapter, will be limited to demonstrating that the international law in force, up to the outbreak of the second World war, did not recognize any legal right of self-determination. The third Chapter. will be an enquiry into the events of the Second World War with the view to showing that those events did not elevate the political principle of self-determination of peoples into a legal right founded on customary international law. Further, the absence of treatment and the treatment given to the concept, respectively at the Dumbarton Oaks Discussions and the San Francisco Conference leading to the adoption of the U.N. Charter, will be discussed, The observations that will proceed from the discussion, will be relied on, in Chapters Four and Five, as an aid to the appreciation of the juridical. content of self-determination as provided for in the Charter. 
In the two succeeding Chapters, that is, in Chapters Four and Five, Articles $1(2)$ and 55 of the U.N. Charter will be treated from the point of view of a lawyer analysing the provisions of a legal instrument with a view to appreciating their juridical and normative consequences relative to the principle of self-determination. To this end, the significance of the word 'principle', the legal effect of the vagueness inherent in the words 'peoples' and 'self-determination' and the general tenor of the two provisions will be considered in order to show that a 'right' of self-determination is not deducible from either Article 1(2) or Article 55 of the Charter.

Apart from the Charter, the other multilateral international instruments that will be given attention are the International Covenants on Economic, Social and Cultural Rights, and on Civil and Political Rights.4 The endeavours in Chapter Six will be directed towards establishing that although, pursuant to instructions received from the U.N. General Assembly, the framers of the two Covenants had the intention of securing, in the covenants,

\footnotetext{
4. Hereinafter referred to variously as 'the Covenants', 'the two Covenants', the two 'Human Rights Covenants' or 'both Covenants'.
} 
a right of self-determination of peoples, the actual words employed in the Covenants 5 were not sufficiently efficacious to translate that intention into a fait accompli.

The subject matter of Chapter Seven will be an enquiry into the possibility of the emergence of a modern customary norm of international law giving rise to the legal right of self-determination of peoples. The enquiry will be necessary and important because, since antiquity is not a prerequisite for the 'growth' of a customary rule of international law, it follows that after showing in Chapter Three that there was no such right in existence, at the inception of the U.N., by virtue of a customary norm of international law, one still has to take into account the possibility of a new customary right of selfdetermination emerging during the period subsequent to 1945 .

A general international consensus that is reasonable is of the essence of a customary norm of international law. Consequently, in the absence of such an international consensus with regard to self-determination, 6 there cannot be a new customary rule of international law to give rise to a right of self-determination of peoples.

5. That is, in Article 1 of each of the two Covenants, to be more specific; the text of Article 1 is exactly the same for both Covenants and so hereafter, a reference to Article 1 of the Covenants or part thereof means Article 1 or part thereof of each of the two Covenants.

6. That is, from the point of view of substance. 
In this connection, the relevance of U.N. resolutions, recommendations and all the other odds and ends which may conveniently be termed 'U.N. practice' cannot be overlooked. On the other hand, the relevance this U.N. practice has to the emergence of a customary rule or norm of international law is not to be exaggerated. Its relevance is evidentiary not creative. In other words, the U.N. practice is relevant not because it per se, 7 creates new customary norms. Its relevance lies in the fact that it may provide evidence of the requisite international consensus which alone can create a customary rule of law.

In substance, what may be termed U.N. practice is a type of consensus formed from the practice of individual states at the U.N. It may thus appear to be a contradiction in terminis for one to aver that U.N. practice is not synonymous with that international consensus which may create customary norms of international law. However, there is no contradiction because U.N. practice incorporates the corporate consensus of states formed within the formal

7. The phrase 'per se' is chosen carefully because even though U.N. practice does not by itself create customary norms of international law, it has such a high persuasive force that it may influence the formation of a norm-creating international consensus and if it does, one can properly say that in an indirect way, U.N. practice has been creative of a customary norm. 
framework of the U.N. only. On the other hand, that international consensus which may have capacity for creating a norm of international law, is general. It emerges not from the resolutions and recommendations of the U.N. alone but from those resolutions and recommendations together with the practice and behaviour of states, statements by authoritative government spokesmen and the pronouncements by statesmen, most of which take place outside the formal framework of the U.N. Thus, one can concede that there has been a consensus at the U.N. on the self-determination of peoples ${ }^{8}$ and, in the same breath, aver that there is a lack of a general international consensus to create a customary right of self-determination of peoples. Chapter Seven will deal more elaborately with the validity of this dichotomy .

At this initial stage, it may be explained, by way of parentheses, that neither the provisions on Mandates in the League of Nations Covenant nor the U.N. Charter provisions on Trust and Non-self-governing Territories will be discussed in the paper. The reason for their exclusion

8. If one does not limit oneself to only the U.N. resolutions on the subject, but goes further into the debates which preceded those resolutions, as well as the number of important states that either voted against, or abstained from voting on, the resolutions, it may be difficult to make even this concession. 
is simply this: The essence of the philosophy behind the Mandate and Trust arrangements as well as the provisions on the Non-self-governing Territories is, government in the interest of the governed and not government by the governed. This philosophy, it is submitted, negates the concept of self-determination because it eliminates the 'self' element. The fact that selfgovernment for the territories involved was the ultimate goal of the Mandate, Trust and Non-self-governing Territories' arrangements does not detract from the submission because it is always an entity other than the particular colonial people concerned that has the right to decide whether or not the people are ready for self-government.

There have been many instances of Non-self-governing peoples being permitted to decide their political future through referenda or plebiscites. 9 It will, however, be observed that even in such cases, an entity other than the colonial people concerned, has to be convinced that the people are probably 'mature' enough to decide intelligently on their future political destiny before a referendum is held. If General de Gaulle had nöt, out of his own volition, decided to hold his 1958 African referendum, the

9. For example, the British Togoland plebiscite of 1956 and the British Cameroons (both North and South) plebiscites of 1961 . 
people of Guinea would have had no means of effectively expressing their determination to govern themselves. In any case, even in referenda and plebiscites, the real wishes of the people are sometimes distorted because the people can choose only from the alternatives offered them. For example, in the British Togoland plebiscite of 1956, the people were asked to choose between an integration with an independent Gold coast on the one hand, and a continued Mandate status pending the ultimate determination of their. political future on the other hand. Had thealternatives been an integration with an independent Gold Coast or immediate independence as a separate Togoland state, the people would most probably have voted for their own independent state.

Thus, the use of referenda or plebiscites in the arrangements involving the Mandate, Trust and Non-selfgoverning Terricories does not change the fact that those arrangements inherently constitute a negation of the principle of self-determination.

To end the paper, Chapter Eight will restate the conclusion flowing from the preceding Chapters. The conclusion is that the concept of the self-determination of peoples may have a legal significance, but so far as rights in international law are concerned, there is not, and there has never been, a legal right of self-determination vested in peoples. 
If the alleged right of self-determination has not had a past and does not have a present, has it got a future? In other words, is there a likelihood that the alleged right will, in the near future, become a right properly so called or a legal right? In furnishing an answer to the question, the salient points made in the paper will be recapitulated to the extent that they bear on a rational prognostication of the future of the 'right'. 
CHAPTER II

THE BACKGROUND TO THE CONCEPT OF SELF-DETERMINATION

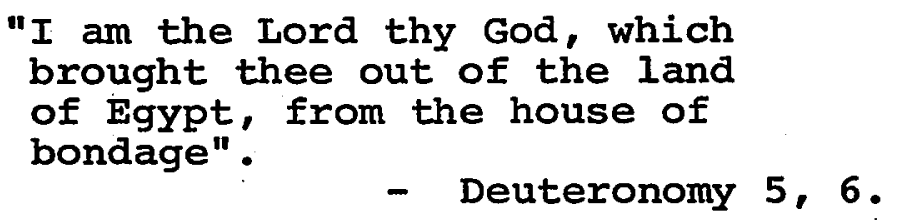

THE ORIGINS AND SUBSTANCE OF SELF-DETERMINATION

The concept of self-determination may apply to groups of people as well as to individuals. In this paper, however, our concern is only with the 'self-determination of peoples'; that is, we are interested in group selfdetermination. The concept has, in the course of history, been applied to different group entities like nations, races, colonies, states and peoples. Whichever group unit one relates the concept, it would be found that self-determination is a concept of considerable antiquity.

The Holy writ reveals that, upon divine inspiration and direction, Moses liberated the people of Israel from the domination of the Egyptians. This act of liberation was calculated to, and it did in fact, result in the people of Israel resettling on "the land of milk and honey" where they, as a people, freely managed their own affairs. To this extent, the whole exodus of the Israelites and their futile pursuit by the Egyptians demonstrated a struggle by a people to obtain and enjoy self-determination. 
If Moses was a hero of the Israelites in their achievement of self-determination in about the 15th Century B.C., Bartolomé de Ias Casas ${ }^{1}$ was, in the 16th Century, A.D., the 'Apostle of the Indians' and an advocate of their selfdetermination. When Emperor Charles $\mathrm{V}$ of Spain asserted his right of annexation of the newly discovered America, then inhabited by Indians, Las Casas boldly opposed it on the ground of self-determination. At a Royal Conference at Barcelona in 1519, he declared inter alia that:

"All nations and peoples, whether they have the faith or not, who have territories and separate kingdoms which they have inhabited from the beginning are free peoples and are under no obligation to recognise any superior outside themselves"."

Though the term 'self-determination' was not employed, it is nonetheless evident from the above dictum that Las Casas was a proponent par excellence of the concept of selfdetermination, which concept he related to 'nations' and 'peoples'.

Another way of putting Las Casas' statement that a people or a nation is "under no obligation to recognise any superior" external to itself is by saying that a nation or a people has the right to refuse to recognise an external superior; that is, it has the right to self-determination.

1. A citizen of Spain, he was born in 1474 and became the Bishop of Chiapas in Guatemala. He distinguished himself by his opposition to Spanish imperialism and colonialism especially in South America.

2. Emphasis supplied; quoted from R.N. Chowdhuri, International Mandates and Trusteeship Systems, (The Hague: Martinus Nijhoff, 1955), pp. 16-7. 
To the extent that Ias Casas may be understood to have alluded to a legal right of self-determination, he was doing no more than indulging in wishful thinking. 3 No rule of the law of nations, as it existed then, prohibited the forcible imposition of an outside superior on a people. The legally unchallenged way in which the colonial European powers grabbed colonies and subjected the inhabitants thereof to domination, is evidence that domination of one people by another was not prohibited under international law. In fact, as recently as in 1937, Professor Yamada of Japan, was appealing to the Tenth International studies Conference in Paris that:

"If we wish to ensure the real peace of the world, we must seek first of all a way of achieving a fair redistribution of colonies. " 4

Still discussing Ias Casas' dictum, it should be observed that if the conquest of a territory and the domination of its inhabitants were permitted under the law of nations, 5

3. That is not to say that, on the moral plane, he was not making a very powerful plea to the Emperor's sense of fair-play.

4. Quoted from R.N. Chowdhuri op. cit., p. 2.

5. It is worthy of note that international law always prohibited interventions in the affairs of other states, if the interventions fell short of a war or conquest, but rather curiously it tolerated full scale wars and conquests; the position has changed, however, with the U.N. Charter's injunction against the use of force (vide Article 2(4) of the charter). 
it would be a contradiction to contend that 'peoples' had the right to reject external domination. This is because an assertion that a 'people' had a right means that theoretically, the law could be invoked for the purpose of vindicating that right. Thus, if the rejection of external domination was a right recognized by international law, the law would, at least in theory, go to the aid of a subject people to remove the external domination they were subjected to. The law would not permit one behaviour and at the same time support the prevention of that behaviour. Since there is no doubt that international law permitted colonialism and there is no evidence of a legal way ${ }^{6}$ of rejecting external domination, a contention that a people had a 'right' to set aside external subjection, would fall. Moving a little nearer to modern times, it would be observed that the concept of self-determination played a role and featured prominently in such monumental political phenomena as the American Revolution against British colonialism ${ }^{7}$ and the 1789 French Revolution.

"When in the course of human events it becomes necessary to dissolve the political bonds which have connected them with another, and to assume among the powers of the eartin, the separate and equal station to which the Iraws of Nature and Nature's God entitle them ....."

6. Whether or not the 'legal way' if any, could have been effectively utilized is another matter.

7. Compare the American Civil War. 
So ran the opening sentence of the American Declaration of Independence of 1776. It makes evident that, at least, one of the reasons for the American Revolution was the desire of the American people to rid itself of British colonialistic tutelage and place its destiny into its own hands. 8 In other words, the Revolution was the desire of the American people for self-determination ${ }^{9}$ translated into political action.10

A new facet of self-determination was surfaced in the turmoil preceding the French Revolution of 1789. The French revolutionaries shouted 'self-determination', but they did not direct the shouts against an alien domination. The shouts were directed against an indigenous monarch. In the sense in which the French revolutionaries used the principle of self-determination, it postulated Rosseau's doctrine that sovereignty resides in the people and that therefore the people should have the power to

8. But soon thereafter the northern states were fighting to prevent the southern states from doing the same, that is, from placing their destiny in their own hands.

9. A dominated country cannot have a status of equality with other free states, including the dominating state, and so it follows that the assumption of equality among "the powers. of the earth" meant the assumption of an autonomous and a self-determining status.

10. If self-determination were a right, there would have been, in theory at least, a legal way by which the Americans could have disencumbered themselves of British rule even against the will of the British. It suffices to point out that no authority has been found suggesting that the Americans could have availed themselves of a legal method to obtain their independence at the time they took it by force. 
organize their government. That is, they must have selfdetermination. In these modern times, however, there is an unjustifiable tendency to use the term 'self-determination' restrictively only in situations in which an alien dominator is involved. Where the authority dominating a people is not external to the people, it is more common to talk about concepts like liberty, freedom and democracy.

As It has been illustrated above, the concept of self-determination is as old as history itself.11 But, whether we regard it as connoting "the exercise by a group of sovereign power of its own",12 or as carrying the import that "every people should be left free to determine its own policy, its own way of development, unhindered, unthreatened, unafraid,"13 self-determination was, up to the time of the First World War, a political principle or concept and no more. The term was devoid of any normative content and nobody even purported it had any. Even as a political principle, it did not command much general application. Benjamin Rivlin has accurately noted that:

11. Inis $\mathrm{L}$. Claude Jr. is thus in error in tracing the genesis of the principle of self-determination to the French Revolution of 1789 ; vide his book, National Minorities, (Cambridge: Harvard University Press, 1955), p. 11.

12. W.R. Bisschop, 'Sovereignty' 'British Yearbook of Internätional Iaw (hereinafter cited as B.Y.I.I.), Vol. II (1921-2), p. 122, at p. 129:

13. Per President Woodrow Wilson; quoted from 'Digest of International Law', Vol. 5 (Washington D.C.: Department of State, 1965), p. 41. 
"Despite general acceptance of this principle Lof self-determination 7 and of its implementation in the nineteenth century, its application was limited for a long time almost entirely to the peoples of Europe. "14

During the First World war, the principle received a boost, experienced a boom and assumed increased importance. THE FIRST WORLD" WAR AND AFTER

In the course of the First World war, President Woodrow wilson emerged as a strong, eloquent and articulate proponent of the principle of self-determination. Because of the zeal and dynamism with which he propagated the idea, it is easy to fall into the error of supposing that he is the progenitor of the concept. 15 He may 16 have created the term 'self-determination', but certainly, the idea that that term bears was not his creature. What he did was that he picked up a dormant principle and revitalized it. He then

14. Vide his article, 'Self-Determination and Colonial Areas', International Conciliation, No. 501 (1954-5), p. 195 at p. 196 .

15. In a debate in the British House of commons on the Treaty of Peace Bill, Prime Minister Lloyd George was taunted by a 'nationalist' M.P. that the principle of self-determination was not being applied to Ireland. He replied: "I tried to apply the principles of President Wilson to Ireland. /An Hon. Member: 'Ah.'T Oh, I did. I tried the principle of self-determination: $\pi$ Vide Parliamentary Debates (Commons), Hansard, 1919, \$o1. 118, Col. 1051.

16. Even his authorship of the term is not free from doubt because it appears the term was being used in socialist literary circles before World War One; for example, vide Lenin, Selected Works, Vol. IV (London: Lawrence \&. Wishart Ltd. , 1936), pp. 249-293. 
gave it new dimensions by emphasizing that self-determination was not just an item of political charity emanating from the strong peoples of the world at their pleasure, but an important political principle vital to the peace of nations and of the world.

President wilson underlined this new dimension

in his 'Four Principles' address to the U.S. Congress on February 11, 1918. He concluded that address by counselling that:
"all well defined national aspirations shall. be accorded theiutmost satisfaction that can be accorded them without introducing new or perpetuating old elements of discord and antagonism that would be likely in time to break the peace of Europe and consequently of the world:

He had earlier declared in the same address that:

$$
\begin{aligned}
& \text { "National aspirations must be respected, } \\
& \text { peoples may now be dominated and governed } \\
& \text { only by their consent. 'Self-determination" } \\
& \text { is not a mere phrase. It is an imperative } \\
& \text { principle of action which statesmen will hence- } \\
& \text { forth ignore at their peril."18 }
\end{aligned}
$$

The President was trying to persuade statesmen to accept his political guideline for the future: He was putting forward a political proposition whose acceptance by the statesmen, especially those of the strong nations, would signify a break with the existing state of affairs under which the

17. Emphasis supplied; vide U.S. Congressional Record, IVI, Part 2, 1952.

18. ibid. 
domination of the weak by the strong had been regarded and accepted as both legally and politically legitimate. This was obviously not a statement suggesting the existence of an international jural norm whose breach could conceivably attract legal sanctions. Rather, it was a statement of what he thought to be a wise political principle whose neglect might result in unfavourably political consequences.

There is ample evidence that President Wilson and some of the statesmen of the pre-1939 years frequently used the word 'right' in apposition to the term 'selfdetermination'. Lenin, for example, published an article entitled 'The Right of Nations to Self-Determination'19 and in one of his writings, he also stated:

"... it would be incorrect to understand the "right to self-determination to mean anything but the right to separate state existence. $" 20$

President wilson himself had in May, 1916, declared that "every people has a right to choose the sovereignty under which they shall live".21 Three years later, in 1919, Senator Léon Bourgeois of France described the concept of selfdetermination as:

19. This was in 1914.

20. Lenin, Selected Works, op.cit.. at p.251 (Emphasis supplied).

21. Emphasis supplied; vide U.S. Congressional Record, IIIl, Part 9, 8854. 
"... la doctrine qui proclame que les peuples ne sont pas des choses, qu'jils ont seuls le droit de disposer d'eux-mêmes.

It may be asked: Did the use of the words 'right' and 'self-determination' in apposition to each other imply that a legal right of self-determination was cognizable under international law? The answer, it is submitted, is in the negative. The word 'right' is sometimes used loosely to designate a social, economic or political desideratum. For example, the peoplé of a state may claim that they have the right to participate in the making of major decisions affecting the state, even though the people themselves may have given to one person a constitutional basis for excluding everybody else from such participation. In such a situation, and speaking as a lawyer, it would be contended that the people have absolutely no 'right' to participate. On the contrary, they are rather obligated to allow themselves to be dictated to and it is the dictator who would have a 'right', the right to dictate or exclude everybody else from participating in the process of decision-making.

On the other hand, on the facts postulated, the statement that the people have a right to participate in the decision-making process would most probably make a lot of

22. Emphasis supplied; quoted from 'Alexandre-Charles Kiss, Repertoire Français De Droit International Public, Vol. II (Paris: Centre National De La Recherche Scientifique, 1966), paragraph 505. 
sense, especially to anybody who goes under the label of a democrat. 23 In this political sense, the statement embodies a political desideratum, namely, the political desirability of achieving for the people, a participatory role in the decision-making process.

To the lawyer, however, to talk about a right that is not grounded solidly on the law, is like running after a legal phantom. 24

There are some bases for propoeing that the word 'right' as used by President wilson and his contemporaries, referred to a mere political right.25 A study of the bulk of the dicta and pronouncements on the right of self-determination of peoples would show that 'right' was used in that context, in the pre-1939 years, loosely and interchangeably with such politics-charged expressions like 'concept',

23. 'Recht' and 'Droit', the German and French equivalent of 'right', also present similar problems of connotation; for example, in French, 'droit politique' may either mean a legal right with a political content or a political principle or ideal - vide footnote 25 below.

24. The famous legal philosopher, william Hearn, said of a 'right' that it "denotes a peculiar legal relation." He added: "It depends exclusively upon the law. It is in the fullest sense the creature of the law". - Vide his book, The Theory of Iegal Duties and Rights, (Iondon: Trubner \& Co., 1883), p. 143.

25. 'Political Right' can be used in two senses: First, it may be used to refer to the political scientist's assertion of a 'right' that has no legal basis, as explained in the foregoing paragraphs. In this sense the 'right' is synonymous with a political principle or ideal. Secondly, it may be used to denote a proper legal right whose subjective content is political, e.g., the electoral laws of a country granting the right to vote, create a political right. In this paper, 'political right' is employed in its former connotation. 
'principle', 'idea', 'ideal' and 'doctrine'... Then, in none of the declarations and speeches on self-determination was it ever suggested that a breach of the principle could occasion legal sanctions. On the contrary, the proponents of the principle frequently warned that its neglect might cause political difficulties.

This probability of unfavourable political consequences following a violation of the principle of selfdetermination of peoples was usually pointed out and emphasized as a means of persuading statesmen and powerful nations to respect the principle.. For example, President Wilson pointed out in a message to the $U \mathrm{~S}$. Senate on January 22, 1917, that "no peace can last, or ought to last, which does not recognize and accept the principle."26

A year later in his 'Four Principles' address to the U.S. Congress, he warned that self-determination "is an imperative principle of action, which statesmen will henceforth ignore at their peril."27 If a legal right of self-determination was acknowledged to exist, at least, some reference to a conceivable legal sanction consequent upon a breach, 28 would have been made in some of the speeches of the President and his contemporary statesmen. No such reference has been found

26. U.S. Congressional Record, LIV, Part 2, 1742.

27. U.S. Congressional Record, LVI, Part 2, 1952.

28. The existence of a legal sanction is indispensable to the existence of a legal right and if there is a sanction but it cannot be easily enforced, that is a matter concerning the effectiveness of the protection of the right and not the fact of the right's existence. 
and this means that they never thought of self-determination in terms of a legal right.

ON THE EVE OF WORLD WAR TWO

Acting pursuant to, and consistently with, his warning that statesmen would neglect the principle of selfdetermination at their own risk, President wilson successfully proposed the endorsement of the principle by the Paris Peace Conference of 1919. In its post-World War One arrangements in Europe, the Conference, as far as possible, allowed itself to be guided by the principle. As it has been noted by Professor Inis claude:
The concept of national self-determination entered significantly into the deliberations of the statesmen assembled at the P.eace Con- ference to determine the European settlement. The Conference allowed and sponsored the operation of that principle ..."29

The Conference, acting upon this principle, prescribed the creation of new states, 30 the adjustment of the boundaries of some of the existing states 31 and even, in some cases, population transfers, 32 in order to avoid national groups losing their self-determination by virtue of their being or becoming minorities in the states of which they were citizens.

29. Vide his book, National Minorities, op. cit., at p. 12 .

30. For example, Czechoslovakia and Yugoslavia.

31. For example, Germany.

32. For example, by a convention, Bulgaria and Greece exchanged nationals - vide League of Nations Document 1927 I.B. 2, pp. 102-5 
In the circumstances, self-determination was not a legal weapon with which all dominated peoples could use to gain their liberation. It was just a handy political tool with which the leaders of the World War One victorious powers and their allies had hoped, and tried, to create a new Europe which would be free from friction resulting from the treatment or maltreatment of national minorities in Europe. Moreover, even though it was held out as a political principle containing much wisdom, it was not intended by its proponents to apply, and it was not in fact applied, outside Europe. Even within Europe itself, the principle was applied only in a limited and sometimes discriminatory way: 33

In view of the fact that the principle of the self-determination of peoples or nations was employed in a limited way to achieve a limited purpose, it was no surprise that soon after the hue and cry consequent upon the First World war had faded away, the principle went dormant again. It needed the turmoil of the second world War to occasion its re-activation.

33. 'Self-determination' was, in fact, more readily invoked to make territorial changes which were to the detriment of one of the defeated powers or one of their allies. 


\section{THE REVIVAL OF SELF-DETERMINATION}

THE SECOND WORLD WAR AND SELF-DETERMINATION

Upon the completion of the territorial arrangements subsequent to the First World War, the principle of self-determination was left sufficiently inactive for it to go into a virtual slumber. However, the principle had enjoyed hardly a quarter of a century of this quiet repose when events in Europe made it experience a rough awakening. The Iiberal-minded: statesmen who participated in the 1919 Paris Peace Conference had entertained the hope and acted on the assumption that a new Europe erected on the principle of national self-determination would become the impregnable cornerstone for a lasiting peace. 1 Unfortunately, no sooner had Hitler risen topower in Germany, in 1933, than he started to use this very principle as the foundation on which he rested his imperialist-expansionist ambitions. 2

1. Vide President Wilson's message to the U.S. Senate on January 22, 1917, quoted supra p. 25 .

2. For example, in a speech to the German Reichstag on October 6, 1939, Hitler justified the German invasion of Poland in late september, 1939, inter alia on the ground that the Polish government had prevented the unification of the German speaking parts of Poland with Germany, contrary to the alleged wishes of the populations of those parts - vide full text of the speech in International Conciliation No. 354 (1939) pp. 495-524, especially PP. 502-5. 
This was patently a perplexing paradox. But even so, if the Germans had limited their ambitions to territories whose populations were of the German stock, they would most probably have been given the benefit of the doubt on the issue of whether or not the German moves were dictated by motives other than a genuine desire to see to it that the principle of self-determination was respected. 3 However, as Hitler's forces overran one victimcountry after another, 4 it eventually became evident, even to the Chamberlains, 5 that the German leader's professed interest in ensuring that the principle of selfdetermination was applied to do justice to Germany, was. but a cunning and treacherous simulation. Germany's real aim was, or at least appeared to be, to deprive all other peoples of the enjoyment of self-determination through the domination of the rest of the world.6

3. In fact, up to a point, such a benefit of the doubt was given to Hitler. For example, at the september 30, 1938 notorious Munich Conference, it was agreed among Britain, France, Italy and Germany that Czechoslovakia ceded to Germany all territories with $50 \%$ or more of the population being of German stock, with a provision for a plebiscite in areas where the percentage was disputed. The agreement shows that the three powers saw merit in the German claims upon Czechoslovakia based on the principle of national self-determination.

4. For example, Austria was annexed in May, 1938 and Poland was invaded in September, 1939.

5. Mr. Chamberlain was a British Prime Minister and a participant in the Munich Conference (vide supra footnote 3 ). He became notorious for his expression of very high optimism, both before and after the Conference, that there was no imminence of war being started by Germany.

6. There is no certainty that Germany would, in the long run, have spared her own allies. 
Faced with the increasing tempo in the physical manifestations of Hitler's territorial expansionist ambitions, the Allied Powers, on the other end, came together in defence of their cherished freedom, their threatened autonomy and their imperilled self-determination. Thus if a one word statement of the issue central to the Second World War were to be asked for, 'self-determination' would be an accurate response.

As it has been noted, 7 at the time of the conclusion of the post-World War One political settlement, selfdetermination was, at best, only a prudent political principle. This means that one can show that there was no general right of self-determination of peoples existing at the time the United Nations Charter came into effect on October 24, 1945, by demonstrating that, in between the end of the First World War and the inception of the Charter, the principle did not go through one, at least, of the only two possible processes of transformation which could have changed the principle into a jural norm generative of a 'right'. One of these two possible processes of transformation, international legislation or the adoption of a multilateral treaty, is revolutionary in character while the other, the emergence of a new customary rule of international law, is evolutionary.

7. That is, supra in Chapter II. 
So far as the revolutionary process is concerned, it would suffice to point out that during this period, 8 no multilateral treaty purporting to create a general right of self-determination of peoples was adopted. The League of Nations' Covenant did not create a right of selfdetermination either by express words or by implication. The nearest thing to a provision for a right of self-determination was contained in Article 22 of the covenant. Paragraph 1 of the Article stated inter alia that:

"there should be applied the principle that the well-being and development of such peoples form a sacred trust of civilization".

Article 22 (2) of the Covenant also referred to "the tutelage of such peoples". What the covenant envisaged, then, was the creation of a situation in which a matured-people would manage the affairs of a child-people in the interest of the latter. This was far from the vesting of a right of self-determination in the peoples of the mandated territories. 9 Did a customary right of self-determination arise within the 1939-45 period? To be able to answer the question in the affirmative, it will be necessary to establish that, in the relevant period, there arose among nations of the world,

8. That is, from 1919 up to the inception of the U.N.

9. Vide supra pp. 11-12, where this point is more elaborately dealt with. 
a consensus both as to the substance or practical aspect of the principle of self-determination and as to the acknowledgement of the principle's binding nature. 10

A consensus of nations was, unfortunately, lacking at both levels. It cannot be said that, during the 1919-1945 period, there was even a general consensus, shared in by civilized nations, with regard to the substance or practical aspects of the principle of self-determination, let alone the existence of such a general international consensus coupled with a further consensual acknowledgement that the principle was binding. Up to 1945, European leaders extolled the virtues of the principle but, at the same time, the powers they represented held on to their colonies without any feeling that they were infringing upon the legal right of the colonized, by the very fact of the colonization. Even if the application of the principle were limited to the Europe of that period, no clear picture would appear. For example, it would have been very difficult to succeed in any attempt to reconcile, on some general and rational basis, the continued retention of the Welsh people under the English monarch, the presence of places outside France but in Europe whose inhabitants were 'predominantly French' and the way the principle of self-determination was sought to be given effect to in the 1938 Munich agreement.1I

10. Vide below, pp $100-5$, for an expanded statement on this consensus theory of customary norm formation.

11. Vide supra footnote 3 , for an explanatory note on the Munich agreement: 
Out of a welter of such apparent irreconcilables, a customary right of self-determination did not, and could not have, come into being.

Despite the role the principle of self-determination played in the political corss-currents of Europe, especially just before and during the second World War, one cannot avoid the conclusion that, at the inception of the U.N. in 1945, the principle remained what it had been in 1919 and before, that is, a prudent political principle and no more.

\section{DUMBARTON OAKS AND SELF-DETERMINATION}

Self-determination was at the centre of the World War Two armed conflict and, during that war, faith in the principle was expressed, emphasized and reaffirmed in documents, statements and declarations emanating from the leaders of the peoples which opposed the Axis Powers.12 In view of this fact, one would have expected that something on self-determination would have found a fitting place in the four-power 13 sponsored Dumbarton Oaks Proposals which

12. For example, in the 'Atlantic Charter' of August 14, 1941, Prime Minister Churchill and President Roosevelt declared inter alia, the desire of Britain and the U.S. to "respect the right of all peoples to choose the form of government under which they will live"; vide also, the "Declaration By United Nations' signed on January 1, 1942, by twentysix countries and which reaffirmed what had been expressed in the 'Atlantic Charter'.

13. That is, Britain, China, U.S.A. and the U.S.S.R. 
later became the basic working document at the 1945 San Francisco Conference which drew up the U.N. Charter. Unfortunately however, self-determination, either as a right or as a mere principle, was conspicuously and mysteriously absent from the Proposals.

Was this omission due to a duplicity of standards ${ }^{14}$ or to innocent oversight on the part of the Four Powers or what, one might ask? An answer to that need not be attempted. For our purpose, it is sufficient to note here that the absence of reference to self-determination in the Proposals greatly reduces any help which might otherwise be derived from the Dumbarton Oaks Proposals, when it comes to the analysis of the legal significance of the UN : Charter provisions covering the principle.

SAN FRANCISCO AND SELF-DETERMINATION

Soon after the end of the Dumbarton Oaks Conversations, the representatives of about fifty countries met at San Francisco for the purpose of drawing up a constitutional document to govern the then projected world organization. At San Francisco, among the amendments introduced to the Dumbarton Oaks Proposals which had become the basic working

14. That is, were the four sponsoring powers suggesting indirectly that once they had successfully defended their self-determination against the German threat, the value contained in the principle had become ipso Eacto spent? 
document at the Conference, was one ${ }^{15}$ by the four sponsoring powers incorporating the principle of self-determination into the Proposals. This particular amendment was proposed for the four-power sponsorship by the Soviet Union which felt that the new world organization should see to it that dependent countries were enabled, as soon as possible, to take the path of national independence. 16 Although the United States had some suspicions that the Soviet Union might utilize the amendment for some sinister ends if it finally became part of the U.N. Charter, the former nonetheless conceded that it would be difficult to oppose the amendment and the principles contained therein.17

There was no discussion within the four-power caucus at San Francisco, and the available records of the Conference do not show that there was a discussion by the Conference, on whether or not 'self-determination', as finally provided for in the Charter has some normative substance.

15. The four sponsoring powers proposed only the amendment which introduced the principle of self-determination in Article $1(2)$ of the present Charter. The same phrase was inserted in Chapter IX, Section A (1) (Article 55 of the present Charter) by the coordination committee vide R. Russell and J. Muther, A History of The United Nations Charter, (Washington D.C.: Brookings Institution, 1958), p. 819; but compare United Nations Conference on International organization (hereinafter cited U.N.C.I.O.) Documents Vol. 3, p. 690 .

16. Vide R. Russell and J. Muther, op.cit., at p. 811 . 17. Vide ibid. 
In its summary report of its sixth meeting, all that Committee $I / 1$ said on self-determination was to point out a division of opinion among delegates.18 One group had asserted that the principle needed universalization in its application while the other would like to have it applied only to the cases of the non-self-governing peoples. CommitteeI/l itself, in the report, did not recommend the adoption or rejection of any of those two views, neither did it put forward a view of its own.

Again, in its subsequent full report ${ }^{19}$ which embodied its own recommendations to Commission $I$, Committee $I / 1$ did not give any direct hint as to the juridical status it had envisaged for the self-determination of peoples' provided for in the Charter. Equally noteworthy is the fact that when the text of Article 1 (2) 20 as recommended by Committee ${ }^{I} / 1$ came for the consideration of Commission $I$, members of the Commission unanimously adopted it by a silent acclamation.

18. Vide U.N.C.I.O. Documents, Vol. 6, p.296; this disagreement was not even over the juridical character of the provision with the amendment but over the extent of the application of the principle contained in the amendment.

19: Vide U.N.C.I.O. Documents, Vol. 6, p. 396.

20. It was Chapter $1(2)$ in the draft proposals but the actual Charter designation is used here to avoid confusion. 
There was no comment, remark or question relating to the juridical effect of the amendment to Article $1(2) .21$ With regard to Article 55,22 committee II/3 recommended 23 the adoption of the amendment basing friendly relations among nations on "respect for the principle of equal rights and self-determination of peoples."24 In this case, too, there was no discussion or decision on the normative effect of the amending phrase.

That the principle of self-determination had gone through a chequered existence up to the birth of the U.N. is apparent from the foregoing pages. From its heyday during the First world War, it subsequently found itself almost in the limbo for forgotten principles for about a decade and a half. Then Adolf Hitler revived it and misused it. The peoples who were frightened by imminent Nazi aggression found it an effective rallying principle. It appeared to have been forgotten at Dumbarton Oaks but it reemerged at San Francisco and found a place in the U.N. Charter without any discussion or controversy over its possible juridical status.

21. Vide U.N.C.I.O. Documents, Vol. 6, p. 65 :

22. This was Chapter IX, Section A (I) in the draft proposals but, again, the Charter designation is being used for clarity's sake:

23. Vide Report of the Rapporteur of Committee II/3 to Commission II, U.N.C.I.O. Documents, Vol. 8, p. 80 .

24. In fact, the exact phrase as used by the sponsoring powers in their amendment passed through CommitteeII/3 and Commission II without any amendment or suggestion of an amendment. 
Throughout all those ups and downs, the principle of self-determination of peoples retained its character as an important principle of international politics. It was not, and it did not become, a norm of customary international law giving rise to rights and obligations cognizable under the law of nations.

After this conclusion, one is tempted to ask: Did the inclusion of the principle in the U.N. Charter amount to a revolutionary step by way of international legislative action transforming an otherwise political principle into a legal right? In other words, did the U.N. Charter, on its inception, create any right of selfdetermination, in the sense that the word 'right' is understood in law?. This question will engage our attention in the two immediately succeeding Chapters. 
ARTICLE 1(2) OF THE UNITED NATIONS CHARTER

"Le droitt des peuples à disposer d'eux-mêmes ne constitue donc pas une règle de droit positif; c'est en réalité un principe politique...."1

SELF-DETERMINATION: A CHARTER RIGHT OR A CHARTER PRINCIPIE?

Article $1(2)$ of the United Nations Charter states

that one of the purposes of the U.N. is:

"To develop friendly relations among nations

based on respect for the principle of equal rights and self-determination of peoples, and to take other appropriate measures to strengthen universal peace." 2

In the absence of some punctuation mark like a comma coming immediately either before or after the 'and' following 'equal rights', the word 'principle' must be taken to apply both to 'equal rights' and to 'self-determination.' The phrase which is therefore up for analysis here is 'the principle of self-determination of peoples'.

The experts who met at San Francisco to draw up the U.N. Charter could not have been unaware of the fact that self-determination had hitherto been only a principle, albeit

1. Per Mon. Juvigny, the representative of France at the $\overline{U . N}$. Economic and Social Council in 1952 -- quoted from Alexandre-Charles Kiss, Répertoire Français De Droit International Public, op. cit., paragraph 509.

2. The French text reads: "Développer entre les nations des relations amicales fondées sur le respect du principe de l'égalité de droits des peuples et de leur droit à disposer d'eux-mêmes, et prendre toutes autres mesures propres à consolider la paix du monde". 
40.

an important one, in international politics for peace. Thus, by the use of the word 'principle', it is submitted that it was the intention of the framers of the Charter that selfdetermination should retain its existing character as a principle. In other words, because of the employment of the word 'principle' in apposition to the 'self-determination of peoples', it is quite reasonable to infer that there was no intention on the part of the drafters of the charter to elevate the principle of self-determination into a legal right. At San Francisco, Committee $I / I$ which had charge of the drafting of Article $1(2)$ referred to 'principle' in its recommendation to Commission I. 3 Commission I itself adopted the whole of Article 1(2), as recommended by Committee $I / 1$, without a comment, question or dissent from any of the members of the Commission. 4

The contention here is that 'principle' was employed selectively and without any misunderstanding or error as to its significance. 5 If a right of self-determination was

3. Vide U.N.I.C.O. Documents, Vol. 6, p. 396; but compare ibid., p. 704, where sub-CommitteeI/1A referred to the 'right' of self-determination. This, however, must be considered as an instance of the common loose use of the word 'right', in view of its disappearance in all the latter drafting stages, after the draft Article had left the sub-Committee.

4. Vide U.N.C.I.O. Documents, Vol. 6, p. 65. 
intended, the drafters of the Charter would have used some appropriate word or words to that effect. It is thus surprising that the significance of the use of the word 'principle' does not seem to be fully appreciated at certain learned quarters, including the councils of the United Nations.

In the deliberations which take place within the Councils of the United Nations, many representatives use the expressions 'the right of self-determination' and 'the principle of self-determination' so interchangeably that one cannot help concluding that those representatives concerned are as yet to make up their minds on what they think is the juridical status of 'self-determination' as provided for in the charter. The type of indecision referred to here, was demonstrated by Mrs. Tsaldaris, the representative of Greece at the U.N. General Assembly's Third Committee. During the Committee's debate on Article 1 of the two Human Rights Covenants, she gave the support of her country to the Article and stated, inter alia, as follows:

"... if individuals and peoples believed in and lived by certain principles, those principles needed to be secured and applied by instruments of application. ... self-determination was a universally recognized principle and right, and that right should be set forth in the Covenants. If the United Nations did not share 
that opinion and if the principles pro-

claimed in the charter were to remain mere

principles that would not be implemented,

the United Nations could have rested content

with the Universal Declaration of Human Rights

and need not have spent years preparing legal

instruments." 6

It is clear from the above quotation that the Greek representative had not made up her mind whether self-determination

was a right or a mere principle.

In fact, the United Nations, as a corporate

body, is also guilty of a failure to make up its mind on

whether the Charter provides for the 'right' or the

'principle' of self-determination. For example, in Resolution

637A (VII) of December 16, 1952, the General Assembly

stated inter alia:

"Whereas every Member of the United Nations, in conformity with the Charter, should respect the maintenance of the right of self-determination 7 of all peoples and nations".

After the General Assembly had referred to the 'right of self-determination' in the preambular paragraph quoted above, it went only as far as recommending that:

"The States Members of the United Nations shall uphold the principle of self-determination $^{8}$ of all peoples and nations". .......

6. Vide U.N. Document A/C.3/SR635, paragraph 3.

7. Emphasis supplied.

8. Emphasis supplied. 
The text of the Charter provisions on self-determination offers no justification for the type of dichotomy that is evident in the quoted clauses of General Assembly Resolution 637A (VII). In the absence of any strong evidence that by 'principle' of self-determination, the drafters of the Charter meant the 'right' of self-determination, it is contended that Article $I(2)$ should be interpreted only as laying down self-determination as a mere guiding principle. 9 Thus, any reference to a charter right of self-determination of peoples, should be viewed as an outright misinterpretation of the Charter or as a backdoor attempt to amend the Charter provisions on selfdetermination by reading 'right' for 'principle'.

THE GENERAL PURPORT OF ARTICLE 1.(2)

The words of Article 1(2), taken as an aggregate, do not carry a normative import. 10 For a right to arise from Article 1(2), it is not enough that the provision forms an integral part of the Charter and that the Charter, as one instrument, is binding upon its signatories. In addition, the words of the provision must, upon a legal construction, be generative of the right that is alleged to arise therefrom.

9. "A fundamental difficulty with the argument that the Charter has created a right of self-determination in subject peoples is that it speaks itself only of a 'principle' and not of a right" per D.P. O'Connell in his book International Law, Vol. I, (London: Stevens \& Sons Ltd., (1965), p. 337 .

10. This, in fact, applies to the whole of Article 1. 
Unfortunately, the words of Article l(2), as they stand, are just a flat declaration of purpose de futuro. Thus, two learned writers were right to have said of Article 1(2) that, in essence, it "is a declaration of goodwill towards peoples which have not yet achieved self-determination"ll and that it does not offer a sufficient basis for immediate claims by such non-self-governing peoples for a change of status.12 The contention that Article $1(2)$ is devoid of a normative content does not mean that the provision does not have much importance. It is certainly of much importance. For example, to the organization itself, the provision constitutes a challenging goal for the achievement of which the U.N. has the legal authorization and competence to direct its endeavours. Also, the provision contributes to help the organization to take calculated steps in a purposeful way rather than grope towards no properly identifiable objective. To the person who just wants to know something about the U.N. and its work, Article $1(2)$ of the Charter is informative because it constitutes notice to the world at large as to one of the objectives which that world organization, as a corporate entity, would strive to achieve. Finally, and to the critic, the provision provides part of the background against which one can undertake either a contemporaneous or

11. Vide N. Bentwich and A. Martin, A Commentary on the Charter of the United Nations, (London: Routledge \& Kegan Paul, 1950), p. 7.

12. ibid. 
an ex post facto assessment of the success or failure of the U.N. in its work.

\section{THE PROBLEM PHRASE}

\section{a) The search for a meaning}

We may postulate that the word 'right' rather than 'principle' is used in apposition to 'self-determination of peoples' in Article 1(2). Again, we may assume that the provision is not, in its tenor, a mere declaration of purpose de futuro, as suggested above.13 In short, we may postulate the employment in Article 1(2) of a phraseology which is such that it ex facie purports to create "the right of self-determination of peoples". It is submitted that, even on these very generous presuppositions, no right of self-determination would become established. This is because "the right of self-determination of peoples" is meaningless. Out of a meaningless phrase, no right can arise.

When an expression carries an almost infinite number of meanings all of which are not just possible but also reasonably probable, then the expression, in fact, has no meaning. This statement contains not only a patent paradox, but also an evident truth. It is not being suggested that a phrase must have one only of what Hans Kelsen terms a "true meaning".14 It is possible and, indeed, usual to have

13. Vide supra, p. 44.

14. Vide Hans Kelsen, Law of the United Nations, (New York: Frederick A. Praeger Inc., 1950), (2nd Impression, 1951), p. xiv. 
an expression having several meanings which are probable. When such a situation arises, it is said that there is an ambiguity and the function of a judicial tribunal, in such a case, is to make a rational selection, out of the competing probable meanings, of the one meaning which the tribunal holds to be the most probable. This is the objective of judicial interpretation properly so called.

At the other end, when the expression in question has, not just several, but many meanings, almost all of which are equally reasonable and probable, the expression ceases to be merely ambiguous and it becomes meaningless or hyper-ambiguous. 15 It is a matter of degree as to where to draw the line between a mere resoluble ambiguity and 'ambiguity' amounting to meaninglessness. It may be difficult to decide on where to draw the line in some cases, but with regard to the phrase "the right of self-determination of peoples", the ambiguity contained therein obviously obtains proportions sufficiently gross to render it meaningless.

What is meant by "the right of self-determination of peoples", it may be asked? Following Professor Cobban, one may define it as the right of peoples to constitute

15. Here, 'meaningless' and 'hyper-ambiguous' are being used synonymously. and hereafter, they and their derivatives will be so used. 
independent states and determine their own governments.16 The first insoluble problem is to determine who constitute 'a people'. There does not appear to be any rational criterion for identifying 'a people' that will not radically affect the existing state boundaries and thereby seriously endanger international peace and tranquility.

If religion is taken as the criterion, we succeed in legally justifyingl7 the break-up of India, as it existed in 1945, into India and Pakistan, as they exist now, only to find ourselves in some difficulty trying to justify the refusal of Moslems-dominated Nigeria to accept the secession of Christian 'Biafrans'. If we were to go a step further and classify 'a people' not just on the broad christian and non-christian lines but on the sub-divisions within those two broad religious grolups, that may result in a reasonable solution, by way of a partition, for the ProtestantCatholic friction in Northern Ireland. But a general application of that classification throughout the world,18 would be subversive of the peace and territorial integrity of many a multi-denominational country; and today, only few countries, if any, could be classified as unidenominational.

16. Vide Alfred Cobban, National Self-Determination, (Chicago: The University of Chicago Press, 1944), p. 45.

17. That is, justifying it on the ground of the alleged right of self-determinations of peoples.

18. Or at least, throughout the territories of states parties to the U.N. Charter. 
Is 'a people' to be classified by language? Should that be answered in the affirmative, all the multilingual countries, especially in Africa, would be in danger of a break-up into micro-states. For example, Ghana is only about 92,100 square miles in area with a population of about eight million, but it has about fifteen languages, six of which are considered sufficiently 'major' to merit separate programmes on the government-owned radio station. This means that a language yardstick for the identification of 'a people' who.should have and enjoy self-determination could reduce Ghana into about six micro-states. If race is resorted to as the yardstick, Guyana could break up into two small states - one for the Negroes and the other for the Indians. A colour criterion would mean that a sovereign state for black Americans would have to be carved out of the United States: On the other hand, a reliance on colour could have some startling results. For example, France could have argued in the Algerian independence question that the issue of self-determination did not arise there since both the French and the Algerians are white.

In order to avoid the problems inherent in the use of colour, race, language or religion as a criterion for determining the unit entitled to enjoy self-determination, one may be attracted by the suggestion of a quantitative criterion. It was suggested about half a century ago that 
'a people', for the purpose of exercising the right of self-determination, should be such a quantum as is "capable of independent existence."19 Today, there are a number of countries that enjoy independent and full sovereign existence with populations of under a million in each case. 20 Relying on this fact, any disgruntled portion of the population of any state could put up a demand for the right to independent existence, if the dissidents could count a million or more in their fold. It is difficult to find a yardstick for identifying 'a people' that would be more potentially generative of international chaos.

Thus, there does not appear to be any rational way of eliminating or even reducing the hyper-ambiguity inherent in the phrase "the self-determination of peoples", and so long as the hyper-ambiguity remains insoluble, so long will the phrase be incapable of bearing a legal right. Recently, the Secretary-General of the U.N., U. Thant, tried probably to confine 'peoples' within limits and thus reduce some of the words hyper-ambiguous nature. He was reported to have asserted that the principle of self-determination

19. Theodore S. Woolsey, 'Self-determination' American Journal of International Law (hereinafter cited as A.J.I.I.), Vol. 13, (1919), p. 302, at p. 304 .

20. For example, Gambia, Barbados and Costa Rica. 
of peoples is not to be applied to parts of the populations within member states of the U.N.21 On that hypothesis of his, he dismissed summarily the Biafran claim for self-determination. However, the Secretary-General's hypothesis is unacceptable because the U.N. Charter, upon which he was apparently relying, refers to 'peoples'. and it is a fact that a member state is not necessarily made up of only one people. 22

If we put aside the insoluble problem of delimiting, on some practicable and rational basis, the unit that may enjoy the alleged right of self-determination, we get enmeshed in the equally insoluble problem of laying down the nature and content of the right; and unless the nature and content of the alleged right is reasonably ascertainable, it cannot subsist as a right.

b) Formal independence and self-determination

Does a people, on obtaining its own state and government ipso facto become self-determined? This question has both an internal aspect and an external aspect.

21. The Secretary-General was speaking in a Radio Ghana interview on January $9,1970$.

22. Compare Australia's Sir Percy Spender's observation, during the U.N. General Assembly's Third Committee debate on Article 1 of the two Human Rights Covenants, that "a people was not necessarily a nation and a nation was not necessarily one people" - vide U.N. Document A/C.3/SR647, paragraph 22 . 
With regard to the external aspect of the question, the U.S.A. rightly answers it in the negative by its frequent charge that the countries which are formally independent but are under Soviet Union's sphere of influence are not self-determined. 23

Concerning the internal aspect of the question, Ciprianos Codas has suggested that the self-determination of peoples should be based on "authentic, free and con- . scious expression of their sovereign will"24 and that "Fraud, fear, violence and civil obfuscation"25 constitute a negation of the right. He added that peoples under totalitarian regimes do not enjoy the right. 26 If his assumption that peoples have a 'right' to self-determination is conceded for the sake of argument, it will be found that his hypothesis commands the support of logic. The U.N. Charter refers to the self-determination of peoples and not states. Thus, if a state i.s independent and self-determining, the people of the state concerned may nonetheless be non-self-determined, if for example, they are smarting under a dictatorship.

23. Vide for example, R. Murphy, 'The Principle of SelfDetermination in International Relations' op. cit., at p. 894 .

24. Vide World Peace Thoughh Law by the Athens World Conference (St. Paul, Minnesota: West Publishing Co., 1964) p. 107 .

25. ibid.

26. ibid. 
In practice, however, there appears to be agreement among member states of the United Nations that the internal power-structure of a member state is not to be questioned in international councils. This agreement is usually rationalized by reference to Article $2(7)$ of the U.N. Charter. But in reality, the agreement thrives on a common East-West desire to have a type of modus vivendi. Thus, where there is an East-West concurrence, as it was the case in the question of General Franco's regime in Spain, the importance of Article $2(7)$ is watered down. To the extent that many international protectors of human rights stop short at penetrating the corporate structure called 'state' to examine if the people in a state are, in fact, collectively determining their own affairs, the Charter provisions on the self-determination of "peoples" have been misconstrued to mean the selfdetermination of 'states'. A possible dilemma that arises here is that, if 'states' is read for 'peoples', then colonial peoples who do not, in international law, constitute states, would have no case claiming that the Charter provisons on self-determination applies to them too. Surprisingly, the U.N. has been operating, in the face of this delimma, with such amazing flexibility that one is left wondering as to what the world organization thinks 'peoples' means in the Charter provisions on self-determination. 
When dealing with member states, the U.N. appears to equate 'peoples' with the legal abstraction known as 'states'. But when it is dealing with non-self-governing countries, the U.N. applies the concept of self-determination to 'peoples' as a collection of individuals. It is not too much to suggest that the U.N. has been able to take actions, in matters involving the issue of self-determination, with that high degree of flexibility because the relevant Charter provisions upon which it relies lay down a political ideal or principle and not a right-creating norm.

In any case, the answer to the question whether or not a people become self-determined by reason only of the fact that they have obtained formal independence, will be conditioned by the answer to the question whether 'peoples' in the Charter provisions on self-determination means a collection of individuals or the state as a corporation. The latter question has: not been answered conclusively in international legal circles and so the former question too is yet to be answered conclusively.

c) The Pan-Africanist philosophy

Is the alleged right exercisable only in certain pre-determined directions? Pan-Africanist opinion which is sometimes supported by some Asian countries, for example, supports a unidirectional exercise of the right subject to a proviso that the direction changes with a change in the colonial circumstances of a people. In other words, the consensus of African opinion is that colonial peoples can exercise the alleged right of self-determination only 
secession-wise by breaking off from the tutelage of the metropolitan countries. Before explaining the proviso, we may refer to the question of Algerian independence because, in that case, the Pan-Africanist philosophy was given some practical expression.

At a meeting of the First Committee of the U.N. General Assembly, in 1958, a joint draft resolution27 on Algeria was presented by a group of 17 states, mainly from Africa and Asia. One of the preambular paragraphs of the draft stated that the General Assembly:

"Recognizing the right of the Algerian people to independence".

The Haitian representative submitted an amendment 28 which was intended to change the above-quoted preambular paragraph to:

"Recognizing, in virtue of Article 1,
paragraph 2, of the Charter, the right
of the Algerian people to decide for
themselves, their own destiny".

The argument of the Haitian representative was that neither the letter nor the spirit of the U.N. Charter authorized the U.N. to indicate to a people the political direction which they should follow and that the Algerian people were free to choose from several other alternatives, two of which were either an integration with France or independence. 29

27. Vide U.N. Document A/C.1/L232.

28. Vide U.N. Document A/C.1/L233.

29. Vide U.N. Document A/C.I/SR.1022, paragraph 40 . 
55.

On behalf of the sponsors of the draft resolution and in what was apparently intended to be a reply to Haiti, Ghana, which only a year before had been a beneficiary of voluntary integration of the former British Togoland, sidestepped altogether the argument of Haiti and merely restated the "conviction" of the sponsors that all peoples had the right to independence. 30 Thus, the sponsors were asserting that the Algerian people could exercise their alleged right of self-determination only in the direction of a total break from metropolitan France. 31

The proviso to the Pan-Africanist philosophy is that upon the people of a colonial country becoming independent, they still can exercise their right of self-determination in only one direction, but this time, in the direction of integration: Thus, while amalgamations like the now defunct GhanaGuinea-Mali Union, and the transformation of Tanganyika and Zanzibar into Tanzania were commended in African circles, the secession bids of Katanga and Biafra were opposed. 32

Two observations may be made from the immediately foregoing paragraphs. First, 'self-determination' lacks a generally accepted precise meaning and to that extent, it does not qualify to be regarded as a legal right. secondly, despite their frequent insistence on the existence of a right

30. Vide U.N. Document A/C.1/SR.1023, paragraphs 1 and 2; the Haitian amendment was defeated.

31. Vide also Repertory of Practice of United Nations Organs, Supplement No. 2, Vol. I, paragraphs 25-8, 55-6.

32. Vide S.K. Panter-Brick, 'The Right to Self-Determination: Its Application to Nigeria', International Affairs, Vol. 4, $(1968)$, p. 254, at p. 258 . 
of self-determination, it seems that the perfectly adaptable use to which African block of countries put the concept of selfdetermination, is suggestive moIe of the fact that they, in reality, regard 'self-determination' as a flexible political principle of convenience rather than a rigid and peremptory precept of international law.

d) The economic constituent of self-determination

Article $1(2)$ of the U.N. Charter says nothing about the economic constituent of self-determination. But this does not mean that at the time of the adoption of this Charter, nobody was aware of that constituent. It is thus justifiable to take into account the economic aspect of the concept in a discussion of the probable meanings and implications of the Charter provisions on self-determination, As far back as almost four decades ago, Professor Quincy Wright was aware of the concept's economic undertones and remarked that:
"Self-determination means that local are to be preferred to foreign interests and this becomes difficult if the latter are more powerful. Thus backward areas dominated by foreign capital or controlled by foreign governments ... seldom get out of such control except by violence." 33

If this remark is not limited to "backward areas" and if it is taken as being descriptive of a constituent of 'self-determination' as provided for in Article $1(2)$ of the Charter, several Western countries would be guilty of violations of self-determination because their capital dominates many foreign countries.

e) The legal effect of the vagueness inherent in the expression "the right of self-determination of peoples" : The foregoing are demonstrative of the futile and enigmatic nature of trying to find for the expression "the The University of Chicaqo Press, 1930), Do. 564-5. 
right of self-determination of peoples", some rational meaning that could be applied generally. Nonetheless, it is appreciated that mere difficulty of interpretation does not affect the normative content of a treaty provision. An international judicial tribunal should, and it frequently does, make considerable effort to find the meaning of many an obscured provision. But, on the other hand, if as in the case of Article I(2),34 the words of the provision, considered carefully, fail to evince any definite meaning which the tribunal can properly attribute to it without the tribunal being guilty of outright axbitrariness, then the only alternative is to declare that that provision is without effect to the extent that it is highly vague. A reasonable degree of definiteness is indispensable in order that a treaty provision may have juridical gravity. If this degree of definiteness is absent, the provision has no gravity and thus cannot stand. If it cannot stand, it follows that it cannot support a legal right. It has been ruled that:

"A legislative act which is so vague, indefinite, and uncertain that the courts are unable, by accepted rules of construction to determine, with any reasonable degree of certainty, what the Legislature intended, or which is so incomplete or conflicting and inconsistent in its provisions that it cannot be executed, will be declared to be inoperative and void." 35

34. For the sake of the argument here, we are still proceeding on the postulate that Article 1 (2) refers to the 'right' and not the 'principle' of self-determination.

35. Per curiam, in Balzer V Caler (1937) 74 p. 2d., 839 at p. 845. 
The dictum is taken from the judgment of a national court in a case involving the construction of a national legislation. But it is a dictum which evidently embodies a common sense rule and so there is no reason why it should not be applied, in the construction of the provisions of an international legislation. If the dictum is applied to the Charter provisions on self-determination, those provisions become inoperative to the extent that they are "vague, indefinite and uncertain".

Even the most loyal supporters of the 'right' of self-determination of peoples would have to concede that such a right could be meaningful only if it is exercised within proper limitations and in proper circumstances. In this connection, it is contended that if a legal right was intended in Article $I(2)$ of the charter, a clearer language would most probably have been used not only in laying down the right, but also in prescribing the conditions for its exercise or enjoyment as well as its limitations. During the discussion of Article 1 of the two Human Rights Covenants at the Third Committee of the U.N. General Assembly, the Swedish delegate expressed a similar view and added:

"Political wisdom required that the whole question should be studied and mapped out before that principle of self-determination was raised to the rank of a right." 36

36. Vide U.N. Document A/C.3/SR64I, paragraph 19. 
One is not unaware of the telelogical school of interpretation which in interpreting a provision of a treaty, de-emphasizes the importance of the text and looks to the broad objects and purposes of the treaty and to "the parties' shared expectations."37 Apart from the questionable validity of the view of the telelogists, 38 it would be observed that even if they are taken on their own plane, a right of self-determination of peoples cannot be recognized under Article $1(2)$ of the Charter. This is an inevitable conclusion because, in the absence of any discussion at the San Francisco conference on the normative effect of the provision's reference to the self-determination of peoples, and the conflicting ex post facto views expressed by the parties 39 to the Charter, it is difficult to identify any expectations with regard to the meaning and implication of 'self-determination' which can be considered to be "shared" by the parties. Thus, not even the liberal telelogical approach can be employed in the circumstances of Article $I(2)$ in which, in order to make some definite

37. M.S. MCDougal, H.D. Iasswell and J.C. Miller, 'The Intexpretation of Agreements and World Order, (New Haven: Yale University Press, 1967), p. xvii.

38. For example, compare Lord McNair's observation that the task of interpretation is to discover the intention of the parties "as expressed in the words used by them in the light of the surrounding circumstances" (his emphasis) - vide his book, The Law of Treaties (Oxford: Clarendon Press, 1961), p. 365; vide alsc C.c. Hyde, International Law, Vol. 2, (Boston: Little, Brown \& Co., 2nd Revised Edition, 1945), p. 1471.

39. Especially during the discussion of Article 1 of the two Human Rights Covenants at the U.N. General Assembly's Third Committee, vide for example, U.N. Documents A/C. 3/SR633-647. 
60.

meaning and recognize a right out of it, a judicial tribunal would have to cross the border of interpretation into the field of rectification and revision. 40 "Rights cannot be presumed to exist merely because it might seem desirable that they should, .41

f) The lack of intention to create a legal right Finally, it may be pointed out that 'self-determination', even as a mere principle, is a politically delicate matter. In view of this, it is very difficult to think of how the parties to the Charter would have created a legal right in respect of self-determination in the apparent uncontroversial way in which Article $1(2)$ was adopted at San Francisco.42 Thus, the contention is ventured that, not only does the hyper-ambiguity in Article l(2) render that provision incapabie of supporting a legal right of self-determination of peoples, but also the intention to create such a legal right was absent on the part of the creators of the $\mathbf{0 . N}$, both at the time the Cherter was being prepared and at the time it was adopted.

40. Vide South West Africa Cases, Second Phase, International Court of Justice .... (hereinafter cited as I.C.J.) Reports, (1966), p. 4, at p. 48 .

41. Vide ibia.

42. Compare the circumstances of the adoption of Article l(2) of the Charter (vide supra, pp.34-7) with those of the adoption of Article 1 of the two Human Rights Covenants (vide U.N. Documents $A / 3077$ and $A / C .3 /$ SR633-677). 
THE INCIDENCE OF OBLIGATION

In any case, if Article $1(2)$ of the Charter were construed as containing a legally cognizable right of self-determination of peoples, there would be very little value in that right because it could be claimed only as against the United Nations and not any of its constituent states members. Since the Advisory Opinion of the International Court of Justice in the Reparation Case, 43 there has not been any doubt that an international organization can possess rights separate from, and independent of, those of its members. There is no reason why an international organization like the United Nations should, conversely, not be capable of bearing obligations also separate from those of the member states.44 In the Charter, where member states of the U.N. have rights or obligations, phrases like "All Members, "45 "A Member" 46 or "Each Member"47 are used. Where both the organization and member states are involved, appropriate words like "The Organization and its Members"48 are employed.

43. I.C.J. Reports, (1949), p. 174 .

44. Article 34 (1) of the I.C.J. Statute states: "Only states may be parties in cases before the court." This may make the enforcement of the rights and obligations of an international organization difficult, but that is a different matter altogether.

45. Vide, for example, Article 2 (2-5).

46. Vide, for example, Articles 5 and 6 .

47. Vide, for example, Articles $9(2)$ and $18(1)$. 
The opening words of Article 1, "The Purposes of the United Nations are", clearly show that what follow in that Article are specifically referrable to the organization. Thus, even if by virtue of Article 1(2), a right of self-determination of peoples has been created, it will be the corporate organization alone that has responsibility for bearing the incidence of the obligation. that may be reflected directly by the right. In such a case, the U.N. could be said to default in its obligations if, for example, it were improperly to send forces into a country's territory.

However, violations and threats of violations of the alleged right of self-determination of peoples are to be feared from states rather than from the United Nations Organization. Therefore, if Article 1(2) per se can obligate only the U.N., any right contained in that provision would, pro tanto, be considerably reduced in its utility.

\section{CONCLUSION}

The arguments made in this Chapter may be recapitulated thus: By the use of the word 'principle' rather than 'right' the framers of the Charter showed that they had no intention of creating a right; 49 secondly,

49. The absence-of-intention argument is bolstered up by the fact of the uncontroversial adoption of the Charter provisions covering the self-determination of peoples. 
had the words of Article I(2) been ex facie positive in expressing the creation of the right of self-determination of peoples, that effort would have been frustrated by the hyper-ambiguity inherent in the phrase "the selfdetermination of peoples"; lastly, Article 1(2) applies to the U.N. and not to its members or to both the U.N. and its members and consequently, if even. a right of self-determination of peoples is deducible from the provision, it is a right of very little value. In contending that only the corporation of the U.N. can possibly have an obligation under Article 1(2), it is not being suggested that member states of the U.N. may not have some obligation in respect of that provision. In fact, to the extent that member states are obliged to help, or at least, refrain from impeding the organization in the achievement of its purposes, member states may have an obligation concerning or in respect of Article $1(2)$, since that provision contains some of the purposes of the U.N. However, such an obligation upon member states would arise as a corollary to the right of the U.N. to receive co-operation from its members and not as a corollary to an alleged right of self-determination of peoples. 
CHAPTER V

ARTICLE 55 OF THE UNITED NATIONS CHARTER

OVERLAPPING WITH ARTICLE 1(2)

Article 55 of the U.N. Charter reads:

"With a view to the creation of conditions of stability and well-being which are necessary

for peaceful and friendly relations among nations based on respect for the principle of equal rights and self-determination of peoples, 1 the United Nations shall promote:

a. higher standards of living, full employment, and conditions of economic and social progress and development;

b. solutions of international economic, social, health, and related problems; and international cultural and educational cooperation; and

c. universal respect for, and observance of, human rights and fundamental freedoms for all without distinction as to race, sex, language, or religion."

Several of the arguments made in the immediately foregoing

Chapter to the effect that no right of self-determination

of peoples is deducible from Article 1.(2) of the U.N.

Charter would apply, mutatis mutandis, to Article 55.

In particular, the following similarities may be pointed out.

1. Emphasis supplied; the phrase is in exactly the same terms as the one appearing in Article $I(2)$. 
First, the original Article 55,2 as presented at San Francisco by the four sponsoring powers in the Dumbarton Oaks Proposals, did not contain any reference to 'selfdetermination'. However, after the four-power amendment had added a reference to self-determination to Article $1(2), 3$ the Coordination Committee inserted the same amending phrase in Article 55.4 When Article 55 was passed through the various stages for detailed study, it was amended in some respects which are not relevent here, but the whole long amending clause containing the reference to 'self-determination of peoples' emerged from the Committee stage 5 and finally from the whole conference intact. The records of the conference do not show any opinion at the conference as to the juridical status the principle of the self-determination of peoples might acquire by virtue of the reference to it in Article 55.6

2. That is, Chapter IX Section $A(1)$ of the Dumbarton Oaks Proposals; for clarity, a reference to Article 55 means Chapter IX Section $A(1)$ of the Dumbarton Oaks Proposals, where the context so suggests.

3. The Article was designated in the Dumbarton Oaks Proposals as Chapter 1(2).

4. Vide U.N.C.I.O. Documents, Vol. 3, p. 690.

5. That is, Committee II/3 of the San Francisco conference.

6. Vide Report of Committee II/3, U.N.C.I.O. Documents, Vol. 8, p. 79; at p. 80 . 
Thus, the conference records do not have much positive interpretative value. The epithet 'positive' is used because the records, in a negative way, may demonstrate that no legal right was contemplated. The creation of a right like the one alleged, which would have very far-reaching political consequences for many countries, would have been subjected to much controversial debate and, most probably, strong opposition, before it was finally adopted. Thus, in view of the fact that the conference records do not show that there was any such controversy over, or opposition to, the amendment, 7 the records negatively confirm that a legal right of selfdetermination of peoples was not intended.

The second point of similarity is that Article 55, like Article 1(2), mentions the 'principle' and not the 'right' of self-determination of peoples. Therefore, if one were to construe Article 55 as being generative of a legal right of self-determination, that would be tantamount to a violent over-stretching of words. 8

7. Vide supra, po.37

8. The more detailed discussion on the significance and implications of the use of 'principle' in Article 1(2) applies mutatis mutandis to Article 55 ; vide supra, pp.39-43; but compare the view of the Byelorussian delegate to the U.N. General Assembly's Third Committee (vide U.N. Document A/C.3/SR 644, paragraph 19). 
Then, as it has already been noted in connection with Article 1(2),9 the phrase 'self-determination of peoples' is hyper-ambiguous to the point of meaninglessness and so the phrase cannot be a bearer of a right.

The fourth and last similarity of the arguments in respect of Article 55 and those in. respect of Article $1(2)$ is that the former Article, like the latter, is referrable to the U.N. as a body and not to the individual member states thereof, nor even to both the world organization and its individual member states. The consequence is that even if a right of -self-determination of peoples were deemed to be created by Article 55, only the U.N. as a corporate legal person would bear the incidence of the obligation arising out of, or in connection with, the right. This would considerably whittle down the importance of such a right. 10

It is to be noted that the argument that is emphasized in the immediately foregoing paragraph does not deny the creation of a legal right of self-determination. The importance of the argument, however, lies in the fact that a state which is confronted with a legal claim, based on Article 1(2) or Article 55 or both, for self-determination, can use it as a second line of defence to parry off the claim, should the tribunal hearing the matter reject the arguments which deny altogether the creation of the right.

9: Vide supra, pp.45-60.

10: Vide also supra, pp: 61-2. 
THE VERBAL STRUCTURE OF ARTICLE 55

It will be observed that Article 55 opens with the words:

"With a view to the creation of conditions of stability, and well-being which are necessary for peaceful and friendly relations among nations based on respect for the principle of equal rights and self-determination of peoples, the United Nations shall promote:"

The Article then concludes with an enumeration of the things and conditions which "the United Nations shall ${ }^{1}$ promote". That the United Nations, by the employment of the verb 'shall' in Article 55, is peremptorily obligated to act is indisputable. The U.N. is under an obligation to act. But what the world organization is required to do is to promote the things, standards and conditions stated in Article 55(a), (b) and (c) and not those mentioned in the opening limb of the Article. Thus, unfortunate though it may be, the consequence of the verbal structure of Article 55 is that, not even a mere promotional obligation has been imposed upon the U.N., as a corporate entity, in respect of any of the things stated in the opening part of Article 55, including the self-determination of peoples. It may be parenthesized that where the obligation is to 'promote', a bona fide maximum effort towards the achievement of the things, standards or conditions to be promoted satisfies

11. Emphasis supplied. 
the obligation. By contrast, if the duty is to 'maintain' or 'achieve' things, standards or conditions, it would appear that anything short of the 'maintenance' or 'achievement' of the things, standards or conditions would amount to a failure to meet the obligation and the cause of the failure would merely be an aggravating or extentuaing circumstance, as the case may be.

The implication of the words "With a view to" in Article 55 is that the creators of the Charter felt that if the standards and conditions laid down in Article 55 (a), (b) and (c) are promoted by the United Nations, the conditions referred to in the opening part of Article 55 would be achieved. This is certainly a hope which may or may not materialize, but there need not be any speculation on that. The point of importance is that, if the U.N. promotes all that is listed in Article 55 (a), (b) and (c), its obligations under Article 55 are wholly discharged. If the discharge of those obligations results in the conditions recited in the opening limb of Article 55, the world would be better off and most people would welcome that. On the other hand, if the promotion of the standards and conditions contained in paragraphs (a), (b) and (c) of Article 55 by the world organization does not result in the establishment of the ideal stated in the opening part of the Article, it would be unfortunate. It may be parenthesized 
here that such an unfortunate result is not at all improbable because the self-determination of peoples is an element of the ideal stated in the opening part of Article 55 and yet, of all the three paragraphs of Article 55, it is only (c) that may, by its use of the broad term 'human rights', be said to cover the selfdetermination of peoples; however, doubt is cast on such a broad construction of 'human rights' because the Universal Declaration of Human Rights which is supposed to be an authoritative interpretation of the Charter provisions on 'human rights', does not contain any reference to selfdetermination either as a right or as a mere principle.

In any case, if the discharge of the promotional obligations contained in paragraphs (a), (b) and (c) of Article 55 does not result in the achievement of the ideal stated in the opening limb of the Article, that would not amount to a default in, or a breach of, an obligation on the part of the U.N. That would only be an unfortunate consequence of an inaccurate judgment on the part of the framers of the Charter in anticipating that the promotion of all the things and standards laid down in Article 55 (a), (b) and (c) would lead to the "creation of conditions of stability and well-being." 
Then, by declaring that "conditions of stability and well-being" are "necessary for peaceful and friendly relations among nations", the framers of the Charter did not merely express a view that may or may not be accurate but they, in effect posited a speculation 12 upon a hope,13 an exercise which does not result in the creation of any right or obligation.

At this stage, the role and importance of 'selfdetermination' in Article 55 comes up for scrutiny. Upon careful examination, it would be observed that the whole phrase "based on the principle of equal rights and selfdetermination of peoples" functions as an adjectival phrase describing the type of "peaceful and friendly relations among nations" that are envisaged under Article 55. Thus, the role of the expression "self-determination of peoples" is quite a humble and passive one, namely, it forms part of the description of conditions which themselves involve neither a right nor an obligation under Article 55.

It is necessary to consider whether the legal situation, in respect of Article 55, as analysed above, would change by reading that Article in conjunction with Article 56 .

12. That is, a speculation that without "conditions of stability and well-being" there cannot be "peaceful and friendly relations among nations".

13. That is, a hope that the promotion of the conditions and standards in Article 55 (a), (b) and (c) will lead to "the creation of conditions of stability and well-being." 
Under Article 56, member states of the U.N. have obligatea ${ }^{-14}$ themselves:

"to take joint and separate ${ }^{15}$ ction in cooperation with the Organization for the achievement of the purposes set forth in Article 55."

The obligation upon each member state is to act, not on its own, but in "cooperation with" the U.N. Thus the essence of the duty imposed upon the signatories to the Charter, by virtue of Article 56 , is to cooperate with the world organization in the realization of the standards and conditions which form the subject matter of the organization's promotional obligation under Article 55.' If, as it has been explained, the organization's duty under Article 55 does not cover the promotion, respect or maintenance of the right or even the mere principle of self-determination of peoples, then the correlative duty of the signatory states, which states merely have to cooperate with the organization, also does not extend, logically, that far. $\underline{A}$ fortiori, it is completely out of place to talk about the positive creation of a legal right of self-determination of peoples, within the context of Article 55 of the Charter.

14. That is, by virtue of the word 'pledge' - vide Report on the Racial Situation in South Africa (U.N. Document A/2505, paragraphs 94-100).

15. The 'joint and separate' implies that, in cooperating with the U.N., a member state may act individually in some respects while acting in conjunction with some other member states in other respects. 
THE LEGAL SIGNIFICANCE OF U.N. RECOGNITION OF THE RIGHT OF SELF-DETERMINATION

The U.N. has frequently, through its General Assembly, recognized the 'right' of self-determination of peoples. It is appropriate to put such U.N. recognitions of the right in their proper legal perspective because, very often, rather too much is read into U.N. resolutions recognizing the right of self-determination of peoples:

One example of how some supporters of the right of self-determination tend to over-value U.N. recognitions of the right will be in place here. In 1955, the U.N. Secretary-General, Dag Hammarskjold, addressed the U.N. General Assembly's Third Committee. In that address,16 the secretary-Gerieral suggested the setting up of an ad hoc committee to attempt to reach agreement on certain basic principles relating to the question of self-determination with the view to embodying such basic principles in a declaration to be adopted by the General Assembly. This, in his view, would be a way out of the political impasse in which the draft Article 1 of the two Human Rights Covenants found itself. Throughout that address, the secretary-General referred to "the principle of self-determination of peoples".

16. Vide U.N. Document A/C.3/L466. 
In the Third Committee's debate on the adaress, a number of delegations expressed their annoyance over the address.17 In particular, the saudi Arabian representative, Mr. Baroody, registered his country's strong objection to the Secretary-General's use of the word 'principle' to describe the self-determination of peoples. Mr. Baroody pointed out that self-determination was not something which was at its theoretical stage of principles but rather it was a right because "it had been recognized as a right by an overwhelming majority of the members of the General Assembly"18 in resolution 421D(V) of December 4,1950 .

Mr. Baroody was articulating a relatively common misconception about the legal significance of U.N. decisions, the misconception that a particular legal opinion reflects the true legal position, by reason only of the fact that that opinion is held by the U.N.. To come specifically to our subject, the question that arises is: Is there a Charter right of self-determination of peoples by reason only of the fact that the overwhelming majority of the members of the General Assembly of the U.N. have supported resolutions recognizing the right of selfdetermination of peoples?

17. For example; Iraq (U.N. Document A/C.3/SR635, paragraph 9), Czechoslovakia (ibid., paragraph 1) and Syria (U.N. Document A/C.3/SR634, paragraph 24).

18. Emphasis supplied, vide U.N. Document A/C.3/SR633, paragraph 19 : 
The answer is in the negative. A political stampede, in arbitrarily selected fact-situations, by a two-thirds or more of the General Assembly, is not necessarily right even morally, let alone legally. The U.N. has facilities for changing the law but that is not the same thing as saying that it is above the law. It is subject to the rules of general international law as well as the restriction and limitations in the Charter which created it. The corporate views of the U.N., as manifested in its resolutions, on what the law is, are entitled to much respect. But all the same it is worthy of emphasis that the U.N. has no special powers to pronounce, conclusively through its political organs, upon the existence of a right if, as it is in the case of the Charter provisions on the self-determination of peoples, the provisions relied upon do not, on a proper legal construction, evince the alleged right. Thus, the fact that the General Assembly has frequently recognized, in its resolutions, the right of self-determination of peoples, does not by itself mean that de jure, there is such a right. 
CHAPTER VI

THE INTERNATIONAL COVENANTS ON ECONOMIC, SOCIAL AND CULTURAL RIGHTS AND ON CIVIL AND POLITICAL RIGHTS

THE GENESIS OF ARTICIE 1

In 1948, the Universal Declaration of Human Rights was adopted by the U.N.. The Declaration, as it was adopted and as it exists now, contains no provisions on the self-determination of peoples either as a concept with a normative content : or as a mere principle. However, in 1952, when the drafting of the International Covenants on Economic, Social and Cultural Rights, and on Civil and Political Rights was in progress, the U.N. General Assembly specifically directed that a provision on the right of self-determination of peoples should be included in both covenants.1 In fact, the General Assembly was so anxious to see the right firmly secured in the Covenants that it did not merely direct that the right be included in the Covenants, but it went a step further to suggest the verbal form the provision should have. 2

1. Vide General Assembly Resolution 545 (VI) of February 5, 1952 .

2. Vide ibid. 
The General Assembly, by commissioning that a 'right' of self-determination of peoples should be provided for in the Covenants, had given the signal for a significant departure from the Charter's phraseological approach to the question because the latter instrument refers to the 'principle' of self-determination of peoples. With this in view, it is reasonable to assume that the General Assembly was contemplating on a provision that would not be a mere guiding principle, but rather a provision that would consecrate the ageless principle of self-deterinnation into a legal right. On this hypothesis will proceed the examination of the question whether or not the contemplated objective of the General Assembly to secure for all peoples a legal right of self-determination, has been effectuated by the two Covenants. 3

THE DRAFTING STAGES

The two Covenants were initially drafted by the United Nations Commission on Human Rights. They were then passed on to the Third Committee of the General Assembly 4 which discussed them in detail and Article by Article before they were passed further on to the General Assembly's plenary session for adoption. 5

3. More specifically, by Article 1 of the Covenants. 4. Hereinafter referred to as the 'Third Committee'. 5. Vide U.N. General Assembly Resolution 2200A (XXI) of 
Attention may now be turned specifically to

Article 1 of the Covenants because it is the provision that deals with the question of self-determination. The Article, quoted in extenso, reads:

"1. All peoples have the right of selfdetermination. By virtue of that right they freely determine their political status and freely pursue their economic, social and cultural development.

2. All peoples may, for their own ends, freely dispose of their natural wealth and resources without prejudice to any obligations arising out of international economic cooperation, based upon the principle of mutual benefit, and international law. In no case may a people be deprived of its own means of subsistence.

3. The States Parties to the present Covenant, including those having responsivility for the administration of Non-Self-Governing and Trust Territories, shall promote the realization of the right of self-determination, and shall respect that right, in conformity with the provisions of the Charter of the United Nations.."

The procedure adopted by the Third Committee in respect of all the final drafting of Article 1 was the following: First, there was a general debate on the Article during which amendments to the Commission's 6 text were proposed; this was followed by the appointment of a Working Party $^{7}$ to re-draft the text; the re-drafted text was then discussed by the full Third Committee which adopted 8 the

6. That is, the U.N. Commission on Human Rights.

7. Vide U.N. Document $\mathrm{A} / 3077$, paragraphs 52-7.

8. Vide U.N. Document A/3077, paragraphs 72-6. 
the final text that was recommended to the plenary session of the General Assembly for adoption. The records of the Third Committee's proceedings on Article 1 thus do constitute a valuable fund from which one cannot but draw upon to a considerable extent, in the course of analysing the normative effect of the Article.

\section{THE CONSTRUCTION OF THE ARTICLE}

\section{a) General remarks}

In Chapter Four, it was argued that the fact that Article 1(2) of the U.N. Charter spoke of the 'principle' of self-determination suggested that the framers of the Charter did not have any intention to secure, by that provision, a legal right in respect of the self-determination of peoples. Then in the same Chapter, we postulated a situation in which the phrase used in Article I(2) of the Charter were "the right of self-determination of peoples" instead of "the principle of self-determination of peoples". Even on that presupposition, it was contended that a proper legal right in respect of self-determination would not be created and vested in 'peoples'. In Article 1 of the two Human Rights Covenants, however, the word 'right' and not 'principle' is actually used in apposition to the expression 'self-determination'. Thus in this present Chapter, we are dealing with a real factual situation and 
not a situation imagined for the purpose of clarifying an argument. It is therefore appropriate here to state, for the sake of emphasis, a point which is obvious and was thus assumed to need no specific mention in Chapter Four. The point is that, the word 'right' is a technical term which connotes a particular legal concept. Two of the indispensable constituents of this concept 'right' are that, there must be an identified or identifi- . able thing or object in respect of which there is the right, and secondly, the entity which or who is designated as the holder of the right must also be identified or identifiable. If these two elements of a 'right' are not present, then the alleged 'right' cannot be a right properly so called or a legal right. As an illustration, if it is said that $M r$. Owusu has a right to $x$, but $x$ is not ascertained and there is no reasonable way of ascertaining what that $\mathrm{X}$ represents, then the right $M r$. Owusu is supposed to have is legally unreal. On the other hand, if it is said that $Y$ has a right to a specific book, but $Y$ who, or possibly which, 9 is supposed to have the right to the book is not ascertained and there is no reasonable way of ascertaining, then as a matter of law, there will be no right to the book because the supposed right will be lacking an identified or an identifiable holder. A fortiori, where

9. That is, the right-holder may be a corporate person and not a natural person. 
both the subject matter of the right and the designated right-holder are unascertained and unascertainable, there will be no legal right:

It follows from the immediately foregoing that the recitation of the word 'right' in respect of something, is not conclusive that, as a matter of law, some entity has a legal right in respect of that something.

With regard to the alleged right of self-determination of peoples, the thing in respect of which there is claimed to be a legal right is 'self-determination' and the supposed right-holders are designated 'peoples' However, as it has been explained in relation to Articles I(2) and 55 of the U.N. Charter, neither the substance of self-determination nor those who constitute 'a people' are ascertained or ascertainable and ipso facto, there cannot be a right of self-determination of peoples. The reasoning in respect of those two provisions of the charter in connection with the juridical effect of the high degree of ambiguity that inheres in the expressions 'self-determination' and 'peoples' will, mutatis mutandis, apply to Article 1 of the two Human Rights covenants.

It is true that Article 1 of the covenants contains clauses which purport to be descriptivelo of what the right of self-determination, as provided for in the Article, embraces.

10. The second sentence of Article 1(1) and the whole of Article $1(2)$ of the Covenants are, at best, only descriptions, and not definitions, of the content of the right of self-determination of peoples. 
But, it is also equally true that those descriptive clauses are themselves very ambiguous and, far from eliminating or even reducing the vagueness inherent in the statement "AII peoples have the right of self-determination" "Il they rather complicate it further.

In the first place, the most important word 'peoples' was left with neither a definition nor a description. In explaining why the U.S.S.R. had voted for Article 1, even though it would have preferred that 'nations' were added to 'peoples' for the purpose of laying down the units or entities to be made entitled to the right of selfdetermination, the U.S.S.R. delegation at the Third Committee stated, inter alia, that "it had been clear from the debate that the word 'peoples' included nations and ethnic groups."12 That was a very good rationalization for the way the U.S.S.R. had cast its vote. But for our purpose, the problem with the vagueness in 'peoples' is not solved by knowledge of some of the entities covered by the expression. To remove the ambiguity, it is an indispensable prerequisite that there should be the possibility of determining, by some reasonable yardstick, the other entities covered by 'peoples':

11. Vide Article $1(1)$ of the Covenants.

12. Emphasis supplied; vide U.N. Documents A/C.3/'SR676, paragraph 49 and A/C.3/SR668, paragraphs $13-6$. 
The problem is how to decide on what criterion or yardstick is practicable and reasonable: For example, the reasonableness of a criterion which appears to have a general acceptance may not stand much scrutiny. It is generally accepted that the people of a colonial territory do constitute 'a people' for the purpose of being entitled to enjoy self-determination. The reasonableness of that is questioned not because it is not important that colonial peoples are able to enjoy self-determination, but because the criterion does not take account of situations in which a country may be formally independent and yet be subject to controls from an external power.13 Although, self-determination is an undefined and, most probably, an undefinable term, it is both unreasonable and dangerously simplistic to limit it to traditional colonial power - colonial country relationship.14

The unreasonableness in other criteria like language, race, colour or religion lies in the fact that any of them is most likely to increase significantly around the world, demands for secession, with their accompanying consequence of world-wide instability that will be generative of international chaos.

13. For example the present U.S.S.R.-Czechoslovakia relationship involves the violation of the latter's self-determination by the former even though Czechoslovakia enjoys formal independence.

14. Compare D.W. Bowett, Self-Determination and Political Rights in the Developing Countries, proceedings of the American Society of International Law, (1966), p. 129 . 
In view of the enigmatic nature of the definitional problem involving 'peoples', one cannot but share with a distinguished Pakistani jurist in his lamentation that:

"... the expression 'all peoples ..... is the most uninformative part of the total text of the Article [Article 1 of the Covenants] and can mean anything or nothing -- according as you have the means of compeliing people to accept one or the other meaning of the expressions used."15

As it has been pointed out, 16 the clauses in Article 117 that may be taken as being descriptive of the contents of the right of self-determination, carry their own ambiguities. Does "freely determine their political status" in Article 1(1) mean that, for example, the French-Canadian people are at liberty to opt out of the confederation of Canada, or it means they are free to determine their political status only to the extent that that status is compatible with the continued existence of the confederation essentially in its present form? In any case, does "freely" mean that the French-Canadian people, in determining their political status, should not be subjected to any political pressures from either the Canadian Federzl Government or the Government of France or

15. Per A.K. Brohi in a 'Foreword' to S. Shaheen's The Communist Theory of National self-Determination, (The Hague: W. Van Hoeve Itd., 1956), p. xiv.

16. Vide supra, pp. $-81-2$.

17. Here and hereinafter in this Chapter, a reference to Article 1 or part thereof means Article 1 or part thereof of the two Covenants. 
85.

both, or it means free from economic pressures emanating from business interests external to French Canada? If by "freely" is implied the absence of physical coercion, then Article $1(1)$ is pro tanto irrelevant through anachronism because in these modern times, foreign influences usually take subtle, sōphisticated and sometimes, imperceptible forms. On the other hand, if "freely":in Article 1(1) implies the absence of these subtle and imperceptible external influences, " then the provison undermines completely any normative vlaue it may possess, by virtue of its being unrealistically and diametically opposed to the hard facts of present day international life. No nation or people can be spared the strong economic, social and cultural influences, intentional or otherwise, emanating from other nations or peoples, unless it is a nation or people cut off from the rest of the world and therefore from civilization too.

b) Article 1, Paragraph 2.

With regard to Article 1(2), it is observed that its first sentence is of no normative consequence. It does not encumber any state or people with a legal obligation, nor does it vest any positive right as such. The verb used 
is "may"18 and so the whole sentence must be taken as laying down a permissive19 way in which all peoples can, if they wish, deal with their natural wealth and resources. The provision contained in the first sentence of Article I(2) does not oblige a people to refrain from disposing of its natural wealth and resources in the interest of a foreign people, nor does it prohibit a foreign people from accepting such a disposition.

But the fact that that first part of Article 1 (2) lacks normative consequence may not mean that it lacks any legal consequence. It is arguable, for example, that a people that seizes foreign owned property may rely on that provision as a legal authorization. This was, in fact, one of the reasons why the leading Western 'capitalist' countries, particularly the U.S.A., voted against Article 1 at the Third committee 20 and have also not become parties to the Covenants. However, the apparent authorization granted under Article $1(2)$ is stated to be without prejudice to any obligations arising out of international law; international law already permits nationalization, provided the nationalizing state complies with certain conditions including the paying of prompt and adequate compensation:

18. Compare the use of "shall" in Article 1(3).

19. That is, in contradistinction to 'mandatory' or 'obligatory'.

20. Vide U.N. Document A/C.3/SR676, paragraph 30 . 
It is evident therefore, that this opening part of Article l(2) does not represent a departure from the existing legal position in international law. Thus, if it was meant to give a legal basis for the renewed ${ }^{21}$ economic dimension that the alleged right of self-determination of peoples had lately assumed, it is submitted that the provision failed to achieve that aim, through failure to employ the appropriate words. It is further submitted that, the states which have not become signatories to the covenants for fear that the property of their nationals, owned in foreign lands, may be subjected to arbitrary seizures and confiscations on the authority of Article I(2), should be taken to have boycotted the Covenants ex abundanti cautela rather than out of a feeling of positive conviction that they would put themselves into a legally vulnerable position, if they should become signatories. Concerning the second sentence of Article 1(2), it is noted that it is very important because, both by its collocation in the scheme of the whole of Article 1(2) and by its peremptory language, it enjoys an overriding dominance over the first part of Article 1(2). The effect of its peremptory language is that if a people enters into a

21. The economic undertones of the concept of selfdetermination has been recognized since, at least, the past four decades, hence the use of the word 'renewed'; vide Quincy Wright, Mandates Under The League of Nations, op. cit. 
transaction which has the effect of depriving that people of its own means of subsistence, then that transaction, will be void, notwithstanding the international law rule that obligations voluntarily assumed are binding.

However, what that second part of Article 1(2) provides for is, in substance, neither the creation of the right of self-determination of peoples nor the recognition of such a right. The provision merely seeks to guarantee a minimum economic security that is necessary for the continued existence of any people gua a people. A people .. that is deprived of its own means of subsistence, has two alternatives -- either to seek subsistence on the means of another people or to remain without any means of subsistence. In the latter case, it will extinct as a people: In the former case, the people may most probably become prone to losing its autonomy and thus its self-determination to the people upon whose means of subsistence the deprived people is obliged to rely.

The immediately foregoing statement is based on the supposition that a people which possesses its own means of subsistence, also enjoys self-determination. It is a notorious fact, however, that a people may possess its own means of susbsistence and yet enjoy no selfdetermination or autonomy. In such a case, the question 
of a loss of self-determination consequent upon a deprivation of a people of its own means of subsistence cannot arise. Thus the fact that the second part of Article I(2) provides a guarantee against the deprivation of a people of its own means of subsistence is not tantamount to either a creation, recognition, or even guarantee against a deprivation, of a right of self-determination of peoples. In other words, if the possession of its own means of subsistence by a people does not necessarily imply the enjoyment of self-determination, then a treaty protection against dispossession of the means of subsistence, is not necessarily a protection against a possible deprivation or denial or self-determination. A fortiori, such a treaty protection cannot be violently stretched to mean actual creation of a right of self-determination.

\section{c) Article 1, Paragraph 1.}

The possible normative effect of the general tenor of Article 1 (1) may now be looked into. The opening part of that provision states: "All peoples have"2 the right of self-determination". The corresponding text recommended by the U.N. General Assembly and also submited later by the U.N. Commission on Human Rights read: "All peoples and all

22. Emphasis supplied. 
nations shall have the right of self-determination".23 It was the Working Party appointed by the Third Committee that changed the "shall have" to "have" and this change was accepted by the full Third Committee, apparently without the members fully appreciating the full legal implications of the change:

If the "shall have" had been retained, it would have been clear that a right of self-determination was being created to take effect at some future date. Nonetheless, since that future date was not stated in the provision, it would have been difficult to say at what precise future time the right would have become operative. This view is shared in by Rosalyn Higgins who also appears to justify the use of the present tense on the ground that it renders self-determination "not as a right enforceable at some future time under indefinite circumstances, but as a legal right enforceable here and now."24 It is difficult to accept her conclusion. The best way of effectively securing the right would have been for the drafters to retain the future tense and specify the future date at which the right would begin to be operative. For example, the provision could have been changed to read "All peoples shall have the right

23. Emphasis supplied; vide U.N. General Assembly Resolution 545 (VI) of February 5, 1952 and U.N. Document E/2573, annex $I$.

24. Vide her book, The Development of International Law through The Political Organs of the United Nations, (London: Oxford University Press, 1963), p. 100. 
of self-determination, upon the coming into effect of this Covenant." The mere change of the future to the present tense was a change from one ineffectual phraseology to an equally ineffectual one.

The desire to "emphaisze the fact that the right referred to was a permanent one" 25 was stated by the Chairman of the Working Party to be the rationale behind the change of tense. The Chairman did not elaborate whether by 'permanent' he was implying that there was a right of self-determination of peoples even before the adoption of the Covenants or that there would, in future, always be a right of self-determination even if the covenants are abrogated, or both. It may not be too far-fetched to suggest that the Chairman and a majority of members of the Working Party probably belonged to the school of thought that holds the view that the U.N. Charter has established a legal right of self-determination or that such a right has come into being subsequent to the inception of the U.N. by virute of a modern customary norm of international law. It is further suggested that their belonging to a school that believed that the right was, at that time, already in existence would necessarily have conditioned their thinking, hence the declaratory tenor that was given to the opening sentence of Article 1(1).

25. Vide U.N. Document A/C.3/SR668, paragraph 3. 
The verb 'have' is a very passive one and, if used in the present tense as it has been used in Article $1(1)$, it implies a status quo. 26 In the context of Article 1(1), 'have' purports to declare an existing fact, the fact of the possession of the right of selfdetermination by all peoples. And it is a notorious observation that a declaratory provision of a treaty merely restates an existing customàry rule. It föllows that the strength of such a declaratory provision varies directly with the validity of the rule the existence of which the declaratory provision assumes. Therefore, with the opening sentence of Article 1(1) merely declaring and not creating a right of self-determination, its normative value depends exclusively upon the validity of the assumption upon which that provision proceeds, the assumption that all peoples possess a right of self-determination. Thus, since there has never been a customary right of selfdetermination either before the inception of the U.N.27 or after, 28 the otherwise inspiring words "All peoples have the right of self-determination", in effect, declares what is non-exjstent and, ipso facto, that provision achieves nothing in the nature of rights and obligations.

26. The French text is no less declaratory in tenor nor is it any less suggestive of a status quo. It reads: "Tous les peuples ont le droit de disposer d'eux-mêmes."

27. Vide supra, Chapters II and III.

28. Vide below, Chapter VII. 


\section{d) Article 1, Paragraph 3}

With regard to Article $1(3)$, its most striking feature is the use of the word 'including' which word, taken with the context, lays at rest any previous views that obligations, if any, in respect of self-determination were to be borne only by the traditional colonial and trustee powers.

The employment of "shall promote" and "shall respect" in Article 1(3) indisputably connote the Intention to create obligations. What obligations? Firstly, there is the obligation "to promote the realization of the right of self-determination" and secondly, there is the duty to "respect that-right" :

On the obligation to "promote the realization of the right of self-determination", it is submitted that that amounts to no more than an undertaking by the states parties to the Covenants to work, bona fide, towards the establishment or creation of that right, that is, the right of self-determination. The contention is based on the combined effect of the expressions "to promote" and "realization". The Oxford English Dictionary defines "to promote" as, inter alia, "to further the growth, development progress or establishment of anything or to support actively the passing of a law or measure, to take the necessary steps 
for the passing of a law"; "to realize" means, inter alia, "to give reality to somethingmerely planned or imagined". The duty to endeavour to secure the creation of the right is altogether different from the duty that would arise if the right of self-determination were effectively established. It is conceded that the intention was to create an outright legal right. 29 However, that intention fails here for want of a choice of appropriate words. 30 It is to be noted that, even though states parties to the Covenants cannot be accused, by virtue of Article 1(3), of violating a legal right of self-determination, in so far as they have assumed obligations towards the achievement of establishment of such a right, they are not to do anything that will run counter to or militate against, the establishment of the right. This means that a state party that acted in disregard of the principle of selfdetermination would be acting in a manner which impedes the elevation of the political principle to the status of a legal right and, to that extent, the state party concerned would be in default of its undertaking under Article 1(3).

29. The pre-adoption debates on Article 1 clearly evinced an intention on the part of the states parties to establish a legal right; for example, vide U.N. Documents A/C.3SR641$665,667-677$.

30. "Many treaties fail - and rightly fail - in their object by reason of the words used." per Lord McNair, The Law of Treaties, op. cit., p. 383. 
With regard to the obligation to "respect that right", it is contended that that part of Article 1(3) results from a putting-the-horse-before-the-cart exercise. One can only respect a right that exists. Thus, the undertaking to "respect that right" is solidly based on the supposition that there is already such a right. Therefore, in the absence of any multipartite international instrument 31 or customary international legal norm 32 establishing the right of self-determination of peoples, the duty to "respect that right" is theoretical and capable of neither performance nor breach.

\section{e) Concluding observations}

Two further points may be stated shortly. The first is that, had Article 1(3) not failed to employ words ex facie creative of "the right of self-determination", that. objective of establishing a legal right would nonetheless have been frustrated by the phrases lack of juridical definiteness. 33

31. If there were any such multilateral international instrument, the right will derive its life from that instrument and not from Article 1(3) of the Covenant.

32. Vide Chapters II and III supra and Chapter VII below.

33. Vide supra, pp . 45-60. 
Secondly, a treaty is res intex alios acta as regards states non-parties and so only signatori states would bear the incidence of the obligations arising out of the alleged right. This means that the refusal by almost all the important countries of the west to become parties to the Covenants, considerably undermines the utility of the right of self-determination of peoples, even if such a right has effectively been established by the Covenants.

The conclusion is that a right of selfdetermination of peoples is not deducible from Article 1 of the Covenants, notwithstanding the clear intention of the drafters to secure the 'right' in the Covenants by Article 1. If this conclusion should be regarded as 'non-progressive' the following words of the International. Court of Justice; in its 1966 judgment of the South west Africa Case, may be borrowed for a rejoinder:

"If, on a correct legal reading of a given situation, certain alleged rights are found to be non-existent, the consequences of this must be accepted. The court cannot properly postulate the existence of such rights in order to avert those consequences. This would be to engage in an essentially legislative task, in the service of political ends the promotion of which, however. desirable in itself, lies outside the function of a court-of-law." 34

34. South West Africa Cases, Second Phase, I.C.J. Reports, op. cit., at. p. 36 . 
MODERN INTERNATIONAI CUSTOMARY IAAW AND THE RTGHT OF SELF-DETERMINATION

OPBNII:G REMARKS

In Chapter Three, it was argued to the conclusion that up to the inception of the U.N., customary international law rules, as they then existed, did not recognize a 'right of self-determination of peoples': 1 In the present Chapter, the objective is to repudiate any suggestion ${ }^{2}$ that the legal position obtaining in the preU.N. years has been altered and that a modern customary rule of international law which establishes the right of self-determination of peoples has come into operation subsequent to the birth of the U.N.

A convenient way of achieving this objective is to give a concise statement of the process of customary rule-formation in international law and to demonstrate that the political principle of self-determination : has not gone through such a norm-creating process.

1. Vide supra. Chapter III, especially pp. 31-3..

2. For example, vide J.G. Starke, An Introduction to International Law, op. cit., p. 120, and Ian Brownlie, Principles of Public International Law, (Oxford: Clarendon Press, 1966), p. 483. 
THE EMERGENCE OF A NEW CUSTOMARY RULE OF LAW

There is weighty authority in support of the proposition that consent is of the essence of the formation of a customary rule of international law. Writing on the emergence of new customary norms of international law relating to the sea, Professor McDougal has observed that customary rule-formation is:

"a process of continuous interaction, of continuous demand and response, in which the decision-makers of particular nation states unilaterally put forward claims of the most diverse and conflicting character to the use of the World's seas, and in which other decision-makers, external to the demanding state and including both national and international officials, weigh and appraise these competing claims in terms of the interests of the world community and of the rival claimants, and ultimately accept or reject them." 3

Another writer has described the process as comprising "the assertion of a right, on the one hand, and consent to or acquiescence in that assertion on the other." 4 Professor Tunkin also lends his support to the consent theory of customary rule-formation and explains that:

3. M.S. McDougal, 'The Hydrogen Bomb Tests and the International Iaw of the Sea', A.J.I.L., Vol. 49 (1955), p. 356, at p. 357 .

4. I.C. Macgibbon, 'Customary International Law and Acquiescence', B.Y.I.I. Vol. XXXIII (1957), p. 115, at p. 117 . 


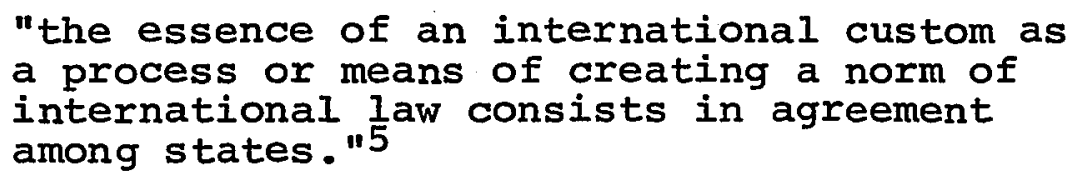

It is generally agreed that this consent or agreement need not be universal' nor does the usage in respect of which this consent or agreement is required: have to be ancient or traceable to a time immemorial. 7 Unfortunately, however, the use of words like

'consent' or 'agreement' to denote an ingredient of customary norm-formation may lead to misleading inferences. For example, one may be misled into thinking erroneously that, if a state has not 'agreed' or 'consented' to a particular general customary rule of law or, where a state has already agreed or consented, if it revokes its consent or withdraws its concurrence, then that state ceases to be bound by that customary rule.

5. G.I. Tunkin, 'Remarks on the Juridical Nature of Customary Norms of International Law', 49 California Law Review (1961) p. 419, at p. 423; vide also D.P. O'Connell, International Law, Vol. I, op. cit., pp. 6-7:

6. Vide J.I. Kunz, 'The Nature of Customary International Law , A.J.I.I., Vol. 47, (1953), p. 662, at p. 666 and G.I. Tunkin, op. cit., at p. 425 .

7. Vide G.I. Tunkin, op. cit., at p. 419 and also J.L. Kunz, op. cit., at p. $66 \overline{6}$. 
A simple and practicable test may be stated as follows: In a particular set of circumstances, if there is a reasonable international consensus to the effect that a particular usage has become a binding. norm of international law, then such a norm may be taken to have come into being. This, in fact, implies a double consensus - firstly, as to the existence and nature of the usage and secondly. as to the usage having become obligatory: The use of the term 'consensus' rather than 'consent' or 'agreement', more accurately connotes the fact that a state may be bound by a particular rule of customary international law 8 even though that state may have neither consented nor agreed to it. Further, the employment of the epithet 'reasonable' is rightly suggestive of the fact that for a consensus to have a norm-creating effect, it must be, in the circumstances, a reasonable one.

Following the above suggested test, it will be appreciated that a concurrence in a given usage by a numerical majority or minority of states is not conclusive as to whether or not the consensus required to transmute the usage into a rule of law has been obtained. For example, if the U.S.A. and the U.S.S.R. should alone follow

8. What is being discussed are general, and not regional, customary rules of international law. 
a particular practice with regard to the use of the surface of the moon, that may be an internationsl consensus reasonable in the present circumstances. 9 Consequently, such a U.S.S.R.-U.S.A. consensus could conceivably -create a customary rule relating to the use of the lunar surface. Conversely, an international consensus on the use of the lunar surface will not be a reasonable one in the present circumstances, 10 and hence not capable of generating a customary rule of law, if both the U.S.A. and the U.S.S.R. do not share in that consensus.

More generally, it may be contended that if none of the states, upon whom an alleged customary norm places an obligation, shares in the consensus backing up the norm, that consensus can hardly be deemed reasonable enough to make the alleged customary norm subsist. EVIDENCE OF INTERNATIONAL CONSENSUS

It follows from the foregoing that an international lawyer seeking to prove the formation of a customary rule of international law, has, in effect, his burden reduced to searching for evidence of the reaching of a reasonable international double-consensus.

9. That is, in the present circumstances in which the U.S.A. and U.S.S.R. are the only states engaged in scientific operations on the lunar surface.

10. Vide supra footnote 9 . 
In other words, the lawyer's task is to gather materials which cumulatively prove that there is a reasonable international consensus, firstly, on the existence and content of the usage that is alleged to have become a rule of law, and secondly, on the fact that the usage has become a rule of law.

In this search, the international lawyer's field of operation is wide. He may look through the debates and resolutions of international organizations of the inter-governmental or inter-state type. He may have to collect in bits and pieces, the decisions of some relevance of national courts, national legislations, pronouncements by statesmen and states-officials, as well as the writings of jurists of high repute. In short, the lawyer may pick up anything that possesses some evidentiary value relative to the fact whether or not a reasonable international consensus exists.

More specifically, it may be emphasized that the debates, resolutions and, in general, the practice of the U.N. do constitute a very valuable source of evidence on the consensual practice of states. This is as it should be because the U.N. has in its membership, over 120 states of varying economic, political or ideological inclinations. 
All these member states are represented by high government officials whose speeches, votes, abstentions and even walk-outs usually reflect the views and feelings of the represented states on specific matters that are in issue.

Thus, it could be said that the U.N. is a type of mirror in which the views and practices of member states are usually 11 reflected and to that extent, its high value as a source of evidence to establish the presence or absence of an international consensus on any matter becomes apparent.

It is quite tempting to say that there is the requisite consensus to create a customary norm of international law simply because the overwhelming majority of countries have supported a particular concept with their U.N. votes over a Iong period. However, if the impression created by the votes is weighed against what the individual states do and how they behave in fact, or with statements by authoritative spokesmen of these states outside the councils of the U.N., the picture that may eventually appear, may be of anything but an international

11. 'usually' but not 'always' because occasionally, the majority may take a decision or act in a particular way in order to get an ad hoc political advantage - in such a case, the reflection would be distorted by politics. 
consensus. That is why one must resist the temptation of equating U.N. practice with the consensual practice of member states, in order to avoid falling into the error of thinking that the corporate practice of the U.N. is, per se, creative of international customary legal norms. By way of parenthesis, it is noted that resolutions of the Security Council, and of the General Assembly,13 may per se bind member states. But such resolutions are in the nature of delegated positive international legislation, 14 the authority to legislate having been delegated, directly or indirectly, by member states; those binding resolutions thus properly belong to a discussion of positive legislation and not customary norm-formation, at the international level.15

The role which U.N. practice plays in the emergence of a new customary rule of international law is only evidentiary and not creative. In other words, U.N. practice does not per se create international customary legal norms. Rather, it may evidence that consensus of states, which consensus alone has creative capacity

13. For example, General Assembly resolutions relating to the internal administration of the U.N. are binding.

14. That is, in contradistinction to customary international legal norms.

15. For a general discussion on the normative capacity of resolutions of international organizations, vide $B$.N. Johnson,"The Effect of Resolutions of the General Assembly of the United Nations', B.Y.I.I., Vol.XXXII (1955-6), p. 97; H.A. Smith, 'The Binding Force of League Resolutions', B.Y.I.L., Vol. XVI (1935), p. 157 . 
relative to international customary legal norms; and even that evidentiary value of U.N. practice may be seriously undermined according as to whether or not the U.N. actions or resolutions were pushed through by an ad hoc political majority, in circumstances showing that very little, if any, objectivity was brought to bear on the specific matters concerned.

SELF-DETERMINATION AS A MODERN CUSTOMARY RIGHT IN INTERNATIONAL LAW?

On the basis of what has been said abovel6 on how a customary norm of international law comes into being, for one to succeed in establishing that since the inception of the U.N. a right of self-determination of peoples has come into being by virtue of a new customary rule of in- ternational law, one has to establish two things. It has to be shown that, in the material period, there has been a reasonable international consensus, firstly on the existence and content of a conception of the self-determination of peoples and secondly, on the fact that peoples may now enjoy this self-determination as of right.

16. Vide supra pp. 98-105. 
With regard to the first requisite consensus, it is conceded that there is a happy coincidence of the minds of many states on the existence of a concept of the self-determination of peoples and the political necessity of all peoples being able to enjoy this self-determination.17 But a closer examination cannot but reveal that it is really a mere theoretical consensus or a consensus on an abstraction bearing the label 'the self-determination of peoples'.

When it comes to the more important question of concrete conducts relating to 'self-determination', the picture that emerges is one of a total lack of international consensus. For example, the U.S.S.R., U.S.A., Britain, Chile and Tanzania all agree, in principle, to the importance of the concept of self-determination, as an abstraction. But in matters concerning the concrete manifestations of that concept, there is much controversy.

17. The inclusion in the U.N. Charter of provisions on the principle of self-determination, as well as the numerous U.N. resolutions on the subject (for example, U.N. General" Assembly Resolutions 1514 (XV) of December $14,1960,2105$ (XX) of December $20,1965,2160$ (XXI) of November 30,1966 and 2403 (XXIII) of December 16, 1968) evidence such coincidence of minds. 
The U.S.A. holds that the U.S.S.R., in its relations with its satellite countries, does not respect the precepts of the concept of self-determination, 18 while the U.S.S.R. denies this and instead taunts the traditional colonial countries for showing disrespect for the concept; Chile protests, 19 contrary to the view of the U.S.A., 20 against the possibility of a negation of a people's self-determination through foreign domination of its natural resources; Britain refused to accept the concept of self-determination as forming a legitimate basis for Katanga and Biafra secessionist attempts, 21 but Tanzania holds that Katanga had no claims to self-determination and, in the same breath, avers that Biafra's claims to self-determination were proper. 22

18. For example, vide R. Murphy, 'The Principle of selfDetermination in International Relations', op. cit.., at p. 894 .

19. Vide Digest of International Law, Vol. 5 (Washington D.C.: Department of State, 1965), pp. 75-6.

20. For example, vide 'Statement by Mrs. Lord', U.S.: State Department Bulletin, Vol. XI, p. 175 .

21. This is an inference from the fact that Britain opposed the seccessionist bid of both Katanga and Biafra.

22. Vide Julius $K$. Nyerere, The Nigeria-Biafra Crisis, (Dar es Salam: Government Printer, 1969), pp. 3-7. 
In short, different states have different and sometimes contradictory views on the elements that form the substance of the 'self-determination of peoples'. What is worse, the views of individual states on what are the constituents of the self-determination of peoples are not only contradictory. Those views also appear to fluctuate according as to who is being accused of a violation of the self-determination of a people. To this extent therefore, there is an absence of that international consensus that can be generative of an international customary legal norm which, in its turn, can be generative of the right of self-determination of peoples. It is true that international consensus has been obtained in concrete instances like the condemnation of the Republic of South Africa for not allowing the South West African people to enjoy self-determination. However, such ad hoc and politically motivated consensus should be deemed as neither sufficiently general nor reasonable to be generative of an international customary legal norm embodying a general right of self-determination.

There is also an absence of the second requisite international consensus, that is, a consensus on the claim that peoples may now enjoy self-determination as of right. ${ }^{23}$ During discussion on Article 1 of the two Human Rights Covenants at the Third Committee of the U.N. General Assembly, 
the U.K. and the Australian delegates sarcastically referred to the "so-called right of self-determination".24

The obvious inference from that taunting sarcasm is that the two countries did not subscribe to the view that the enjoyment of self-determination had become a right. There is no evidence that the U.K. or Australia or the other countries which, at that time, denied the transmution of the principle of self-determination into a customary right, have now changed their view.

In order probably to circumvent the difficulty of establishing the necessary international consensus to the effect that self-determination has become a customary right in international law, some over-zealous protagonists of the alleged right intimate that the right arises by necessary implication in that, without it, all other human rights become nugatory. 25 This argument is unconvincing because if it is pressed to its logical conclusion, it would have the absurd result of reducing the Universal Declaration of Human Rights, that Magna Carta of the World, into a worthless

24. Vide U.N. Documents A/C.3/SR635, paragraph 26 and A/C.3/SR647, paragräph 21; some other important countries like Sweden (vide U.N. Document A/C.3/SR64I, paragraph 15) and Canada (vide U.N. Document A/C.3/SR653, paragraph 20) also directly or indirectly rejected claims that such a legal right exists.

25. For example, vide the draft resolution tabled at the U.N. General Assembly's Third Committee jointly by Saudi Arabia and Afghanistan (U.N. Document A/C.3/L474). 
document containing a string of platitudes, by reason only of the fact that it contained no provisions on selfdetermination. Happily, it is simply not true to say that the enjoyment of self-determination is an indispensable pre-condition for the enjoyment of all other human rights. For example, the péple of Ghana enjoyed freedom of expression, freedom from arbitrary imprisonment and other human rights when Ghana was a colony. Ironically, it is a fact that the Ghanaian people rather lost many of their human rights for a period of about a decade, subsequent to their becoming a self-governing people.

Finally, it is appreciated that a claim that a legal right of self-determination has now come into being, by virtue of customary norms of international law, carries with it, by implication, a further claim that important countries like the U.K., Australia, Canada and the U.S.A. which specifically opposed 26 Article 1 of the two Human Rights Covenants and have refused to become signatories to the Covenants can, nonetheless, be saddled with obligations that may be reflected by the alleged right. This is so because if a right is based both on a customary norm of international law and on treaty law, countries, which are not signatories to the treaty are nonetheless obligated to respect the right since their concurrence is not necessarily required in order for them to be bound by the customary norm on which the right is based. 
The claim that the non-signatories to the two Human Rights Covenants are nonetheless obligated to respect the alleged right is so serious that it has to be rejected, in the absence of very solid grounds to back up the claim. For example, there would be such a solid ground if the Covenants had, in very clear terms, stated that Article 1 was codifying an already existing customary rule of international law and the many nonsignatories had refused to become parties for reasons not amounting to a challenge that such a customary rule or norm already exists.

\section{CONCLUSION}

It may be said, in conclusion, that it certainly will be in the interest of international peace and tranquility if peoples allowed themselves to be guided by the principle of self-determination. But it will be wrong for one to pretend that the principle has now been consecrated into a legal right, by virtue of a modern customary rule of international law, if there is not the requisite international consensus on the content of the principle, the units which may be beneficiaries of the principle, and on the fact that the principle has now acquired a normative character. 


\section{CHAPTER VIII}

\section{CONCLUSION}

In the preceding Chapters, the concept of self-determination of peoples was subjected to legal scrutiny with the view of appreciating what legal reality, if any, the concept possesses within the framework of international law.

Shortly stated, the conclusion that flows from the scrutiny is that international law does not have, and has never had, provision for a general right of self-determination of peoples. "This conclusion is essentially based on two broad factors, namely, structural ineffectiveness and substantive vagueness. In other words, there is no legal right of self-determination of peoples, firstly, because each of the multilateral treaty provisions allegedly establishing the right has a verbal structure which, upon a proper construction, fails to evince the alleged right, and secondly, because the concept of the self-determination of peoples is so vague in its substance that the claimed right cannot be founded upon it. 
These two factors are periinent to an assessment of the future of the 'right'. The structural problem, relevant only in a discussion of a possible treaty right of self-determination, can be eliminated without much difficulty through the exercise of more care in the drafting of any future treaty intended to provide for the right. Thus : the substantive vagueness factor remains the only serious problem that stands in the way of the elevation of the 'right' into a right properly so called. In this connection, the process of customary norm-formation is ill-suited for overcoming the problem. There has not so far been a customary right of selfdetermination of peoples because states have frequently differed diversely as to which situations do, or do not, involve the issue of self-determination to the extent that the international consensus required to give rise to such a customary right has not been achieved. No grouncis appear to exist for any optimistic expectation that the views of states on the content of the concept of the selfdetermination of peoples will, without any positive steps to co-ordinate those views, become sufficiently concurrent to result in the achievement of a norm-creating international consensus that will be generative of the right of selfdetermination. 
With the almost infinite elasticity of the principle or concept of self-determination, it is only through a positive co-ordinated action, by way of international legislation, that an international concurrence on what exactly the concept involves can be obtained.

It follows that he who wishes to see the right of self-determination of peoples find a place in international law, should direct his endeavours towards the preparation and adoption of an appropriate multilateral treaty of general application. In this direction, too, there are no grounds for optimism about the future. In a treaty, it will be extremely difficult to define 'selfdetermination' and 'peoples' in any clear and meaningful way without scaring off from becoming signatories, some important members of the world family of nations. For" example, if a convention defines 'self-determination' to give it some exonomic undertones so as to legitimatize the confiscation or arbitrary nationalization of foreign owned property, most of the Western countries whose capital dominate many foreign countries, will most probably not become parties to it with the inevitable result that the convention will fail to have the desired impact on the world scene. 
Again, for example, if the unit of people in whom a treaty vests the right is defined on language lines, most of the states with two or more language groups will, most probably, decide not to become signatories to the treaty. Whatever definition you give to 'people' and 'self-determination', the states which get the slightest apprehension that some material interest of theirs might be adversely affected, will refuse to bind themselves under the international instrument concerned.1 In these circumstances, an example of the pertinent questions which will have to be answered is: of what real value is a treaty providing for the right of self-determination of peoples, with 'peoples' defined on linguistic lines, if only unilingual states are parties to it?

A way of effectively avoiding any material boycott of a treaty creating the right is to leave the phrase "the right of self-determination of peoples" altogether undefined or defined in terms so vague that states can feel sure that they can become signatories without rendering themselves legally vulnerable in any of their material

1. For example, the main reason for the refusal of many Western countries to become parties to the two Human Rights Covenants was their fear that Article 1 of the Covenants might be relied upon to expropriate arbitrarily, property owned abroad by their nationals. 
interests. Unfortunately, however, such a high degree of vagueness as will induce a large number of states to become parties to the multilateral international instrument, will have the additional and unwelcome consequence of rendering juridically nugatory the provision that ex facie purports to create a legal right of self-determination of peoples. Another factor making it improbable that an effective international instrument will be adopted, in the forseeable future, to establish the right is that, despite all appearances to the contrary, the concept of self-determination is progressively becoming irrelevant in world affairs. U.N. Secretary-General, U. Thant, in his January, 1970 African tour, was reported by Radio Ghana to have said that the concept of self-determination does not apply to populations within a member state of the U.N. and added, in more specific terms, that it did not apply in the Nigeria-Biafra conflict. If this particular view of the Secretary-General is accepted as an accurate articulation of world opinion, 2 then the principle of selfdetermination is deemed currently to apply only in interstate, and in colonial power-colonial territory relationships.

2. The Secretary-General's statement has been criticized above (supra p.50), but from an observation of the world scene, for example, the way secessionist bids within U.N. member states have received no world sympathies, it looks like he was, in fact, verbalizing the existing feeling among states. 
Therefore, with the eventual demise of traditional colonialism, which demise is expected not in a too distant future, the principle will have application only in inter-state relations.

But in any situation in which one state may properly claim that it is being prevented by another from determining its own affairs, it would appear that the victim state would have some legal grounds more concrete and more certain to support a charge against the offending state, than the ground of a violation of a so-called right of self-determination. The victim state may be able to charge that the accused state is, for example, violating the former's territorial integrity ${ }^{3}$ or sovereignty, or intruding into its domestic affairs, 4 or the offending state may be accused of acting in a manner amounting to a threat to, or a breach of, international peace and security. 5 The 1968 U.S.S.R. led Warsaw Pact powers' 'invasion' of Czechoslovakia may be cited for a specific illustration. In that case, anybody wishing to impugn on the legitimacy of the 'invasion' may find it more fruitful to argue that the 'invasion' constituted an unsolicited intervention in

3- Vide Article 2(4) of the U.N. Charter.

4. Vide ibid., Article $2(")$.

5. Vide ibid., Article 39 . 
Czechoslovakia's domestic affairs, or a violation of its territorial integrity, or a situation threating international peace and security than to dissipate effort arguing on the very weak ground of a violation of a socalled right of self-determination.

Thus, the existence of several alternative legal grounds more solid and less elusive-than the ground based on the concept of self-determination of peoples will have the effect of making it both unnecessary and improbable that efforts will be made in the near future to secure the adoption of a multilateral international instrument that will effectively legislate the right of selfdetermination of peoples.

It is appropriate to add that the proposition that there is not a legal right of self-determination of peoples is not equivalent to stating that the concept of self-determination cannot have a legal significance. It certainly can. For example, under the enforcement procedures contained in Articles 39 to 42 of the U.N. Charter, the security Council is not restricted in choosing a basis for its subjective determination that a threat to, or a breach of, peace exists. 6 Once the council has determined

6. Vide N. Bentwich and A. Martin, A Commentary on the Charter of the United Nations, op. cit., p. 88, and J.I. Brierly, The Law of Nations, Toxford: Clarendon Press, 6th Edition, 1963), p. 382. 
that a threat to, or a breach of, peace exists, it can act under those enforcement provisions, and the question of whether or not the threat arose out of an otherwise domestic matter, or a violation of a purely political principle, or a default in a legal obligation by violating a legal right, becomes irrelevant.

It follows that if one can show in specific cases that refusal to respect the principle of selfdetermination has created a situation amounting to a threat to, or a breach of, international peace, the Security Council can be seised with -ompetence to act within the powers conferred on it by Articles 39 to 42 of the U.N. Charter and it will be unnecessary to determine the question whether or not there is a legal right of selfdetermination. In the South-West Africa Case, for example, if African countries raise sufficient. hue and cry and exhibit physical manifestations of their annoyance at the situation to the extent that the security Council. gets satisfied that a trreat to international peace has arisen, the Council will be seised with competence to act to rectify the situation. If the Council decides that it is the refusal of South Africa to let the people of South-West Africa enjoy self-determination and not the behaviour of the African countries that is the cause of the threat to peace, the Council can act accordingly without getting involved in the determination of a preliminary question as to whether or not 
the people of South-West Africa have a legal right to self-determination. However, the converse must also be emphasized that the fact that the principle of selfdetermination of peoples may have a legal significance does not mean that there is a legal right to the interests proclaimed by the principle. Finally, it may be restated in conclusion that, despite some utterances to the contrary, and despite some positive international efforts to effect a change through multipartite international legislation, the concept of self-determination of peoples remains today what it was during the presidency of Woodrow Wilson and before -- a political desideratum. 


\section{BIBLIOGRAPHY}

BOOKS

Athens World Conference, World Peace Through Law, (st. Paul, Minnesota: West Publishing Co., 1964).

AUSTIN J., Iectures on Jurisprudence, Edited by R. Campbell, (Iondon: 'Sheratt \& Hughes, 5th Ed., 1911).

BENTWICH N., \& MARTIN A., A Commentary on the Charter of the United Nations, (London: Routledge \& Kegan Paul, 1950).

BROWNLIE I., Principles of Public International Law, (Oxford: Clarendon Press, 1966).

CHOWDHURI R.N., International Mandates and Trusteeship Systems, (The Hague: Martinus Nijhoff, 1955).

CLAUDE Jr. I.I., National Minorities,

(Cambridge: Harvard Univ. Press, 1955).

COBBAN A., National Self-Determination,

(Chicago: The Univ. of Chicago Press, 1944).

DIAS R.W.M., Jurisprudence, (London: Butterworths, 2nd

Ed., 1964):

GANJI M., International Protection of Human Rights

(Paris:" Librairie Minard, 1962).

GOODRICH L.M. \& HAMBRO E., Charter of the United Nations (Boston: World Peace Foundation, 2nd Ed., 1949).

GREEN J.F., The United Nations and Human Rights, (Washington D.C.: The Brookings Institution, 1956).

HALASZ $J$. (Edited), The Socialist Concept of Human Rights, (Budapest: Alcađémiai Kiado, 1966).

HEARN W., The Theory of Legal Duties and Rights, (Iondon: Trubner \& Co., 1883).

HIGGINS R., The Development of International Law through the Political Organs of the United Nations, (London: Oxford Univ. Press, 1963). 
HYDE C.C., International Iaw, Vol. 2

(Boston: Iittle, Brown \& Co., 2nd Ed., 1945).

JOHNSON H.S., Self-Determination Within the Community of Nations, (Leydon: A.W. Sijthoff, 1967).

KEDOURIE E., Nationalism, (London: Hutchinson Univ. Library, 1961).

KELSEN H., General Theory of Law and State,

(Cambridge: Harvard Univ. Press, 1945).

- Law of the United Nations,

(New York: Frederick A. Praeger Inc., 1950).

- Pure Theory of Law,

(Berkeley \& Los Angeles: Univ. of California Press, Translation of 2nd Ed., 1967).

KOHN H., The Idea of Nationalism, (New York: The Macmillan Co., 1945).

LADCR-IEDERER J.J., International Group Protection,

(Leydon: A.W. Sijthoff, 1968).

LAUTERPACHT H., International Law and Human Rights,

(London: Stevens \& Sons Ltd., 1950).

LENIN V.I., Selected Works, Vol. IV

(London: Lawrence \& Wishart Lta., 1936).

LLOYD D., Introduction to Jurisprudence,

(Iondon: Stevens \& Sons, 2nd Ed., 1965).

LUARD E. (Edited), The International Protection of Human

Rights, (London: Thomas \& Hudson, 1967).

MCDOUGAL M.S., LASSWELL H.D. \& MILLER J.C., The Interpretation of Agreements and World Order, (New Haven: Yale Univ. Press, 1967). MCNAIR (Lord), The Law of Treaties, (Oxford: Clarendon Press, 1961).

O'CONNELL D.P., International Law, Vol. I, (London: Stevens \& Sons Itd., 1965).

POLLOCK F. (Sir), A First Handbook of Jurisprudence,

(London: Macmilian \& Co. Itd., 6th Ed., 1929). 
RUSSELI R. \& MUTHER J., A History of the United Nations Charter, (Washington D.C.: Brookings Institution, 1958).

SCELLE G., Précis de Droit Des Gens, Deuxième Partie, (Paris: Libraire du Recueil Sirey, 1934).

SHAHEEN S., The Communist Theory of National SelfDetermination, (The Hague: W. Van Hoeve Ltd., 1956).

STALIN J., Marxism and the National Question, (Moscow: Foreign Languages Publishing House, 1954).

STARKE J.G., An Introduction to International Law, (London: Butterworths, 6th Ed., 1967).

VERZIJL J.H.W., International LaW in Historical Perspective, Vo1. I, (Leyden: A.W. Sijthoff, 1968).

World Federation of United Nations Associations, The Legal Principles Governing Friendly Relations and Co-operation Among States, (Leydon: A.W. Sijthoff, 1965).

WRIGHT Q., Mandates Under the League of Nations, (Chicago: The Univ. of Chicago Press, 1930). 
ARTICIES

BISSCHOP W.R., 'Sovereignty', B.Y.I.I., Vol. II, (1921-2); p. 122 .

BOWETT D.W., 'Self-Determination and Political Rights in the Developing Countries'. Proceedings of the American Society of International Law, (1966), p. 129.

EAGLETON C., 'Excesses of Self-determination', Foreign Affairs, Vol. 31, (1952-3), p. 592 .

--, 'Self-determination at the United Nations', A.J.I.I.: Vol. 47, (1953), p. 88 .

EMERSON R., 'Self-Determination', Proceedings of the American Society of International Law, (1966), p. 135.

GOODMAN E.R., 'The Cry of National Liberation: Recent Soviet Attitudes Towards National Self-Determination', International Organization, Vol. 14, (1960), p. 92 .

HULA E., 'National Self-Determination Reconsidered'. Social Research, Vol. 10, (February, 1943), p.1.

JESSUP P.C., 'Self-Determination Today in Principle and in Practice', Virginia Quarterly Review, Vol. 33 (1957), p. 174.

JOHNSON D.H.N., 'The Effect of Resolutions of the General

Assembly of the United Nations', B.Y.I.I., Vol. XXXII, $(1955-5), p .97$.

KUNZ J.I., 'The Nature of Customary International Law', A.J.I.L.; Vol. 47, (1953), p. 662 .

MACGIBBON I.C., 'Customary International Iraw and Acquiescence', B.Y.I.L., Vol. XXXIII, (1957), p. 115 .

MARTIN E.M., 'Interdependence and the Principles of SelfDetermination and Nonintervention ' U.S. State Department Bulletin, Vol. XIVIII, (1963), p. 710:

MCDOUGAI M.S., 'The Hydrogen Bomb Tests and the International Law of the Sea', A.J.I.I.., Vol. 49, (1955), p. 356.

MURPHY R., 'The Principle of Self-Determination in International Relations', U.S. State Department Bulletin Vol. XXXIII (1955), p. 889. 
PAIMER J., 'The Concept of Self-Determination in American Thought', U.S. State Department Bulletin, Vol. XXXVIII, (1958), p. 824.

PANTER-BRICK S.K., 'The Right to Self-Determination: Its Application to Nigeria', International Affairs, Vol. 4, $(1968)$, p. 254 .

RIVLIN B.,' 'Self-Determination and Colonial Areas', International Conciliation, No. 501 (1954-5), p. 195.

SMITH H.A., 'The Binding Force of League Resolutions', B.Y.I.L., Vol. XVI, (1935), p. 157 .

STEVENSON A., :Ü.N. General Assembly Urges Portugal To Promote Self-Detërmination for Angola', U.S. State Department Bulletin, Vol: XIVI, (1962), p. 385 .

TUNKIN G.I., 'Remarks on the Juridical Nature of Customary Norms of International Law', California Iaw Review, Vol. 49, (1961), p. 419 .

WINDASS G.S., 'Power Politics and Ideals The Principle of Self-Determination', International Relations, Vol. III, No. 3, (1967), p. 177 .

WOOLSEY T., 'Self-Determination', A.J.I.I. Vol. 13, (1919), p. 302 .

WRIGHT Q., 'The Goa Incident', A.J.I.I., Vol. 56, (1962), p.617.

- , 'Recognition and Self-Determination', Proceedings of the American Society of International Law, (1954), p. 30 .

--, 'Rhodesia', A.J.I.L., Vol. 62, (1968), p. 1. 


\section{MISCELLANEOUS}

Digest of International Law, Vol. 5, (Washington D.C.: Department of State, 1965).

KISS A.-C., Répertoire Français De Droit International Public, Vol. II, (Paris: Centre De La Recherche Scientifique, 1966).

NYERERE J.K., The Nigeria-Biafra Crisis, (Dar es Salam: Government Printer, 1969).

Parliamentary Debates (Commons), Hansard (1919) Vol. 118.

Reparation for Injuries Suffered in the Service of the United Nations, I.C.J. Reports, (1949), p. 174 .

'Statement by Mrs. Lord', U.S. State Department Bulletin, Vol. XI, (1959), p. 175.

South West Africa Cases, Second Phase, I.C.J. Reports, (1966), p.4.

Tanzania Government's statement on The Recognition of Biafra, (Dar es Salaam: Government Printer, 1968).

Text of Chancellor Hitler's Speech before the Reichstag, October 6, 1939, International Conciliation, No. 354, (1939), p.495.

United Nations Documents:-

A/3077

A/C. 1/L232-3

A/C.1/SRI022-3

A/C. 3/I466

A/C. $3 / \mathrm{L} 474$

A/C. 3/SR633-677

$\mathrm{E} / 2573$, annex I. 
vii

General Assembly Resolutions:-

545 (VI) of February 5, 1952

637A (VII) of December 16, 1952

1514 (XV) of December 14, 1960

$2105(\mathrm{XX})$ of December 20, 1965

2160 (XXI) of November 30,1966

2200A (XXI) of December 16, 1966

2403 (XXIII) of December 16, 1968.

Repertory of Practice of United Nations Organs, Supplement No. 2, Vol. I.

Report on the Racial Situation in South Africa (Document A/2505).

U.N.C.I.O. Documents, Vols. 3, 6 and 8 .

United states Congressional Records, Illl, Part 9 and LVI, Part 2 . 